\title{
Diastereoselective Synthesis of Glutamate-Appended Oxolane Rings: Synthesis of $(S)-(+)$-Lycoperdic Acid
}

\author{
Jamie L. Cohen and A. Richard Chamberlin* \\ Department of Chemistry, University of California, Irvine, \\ Irvine, California 92697
}

\section{Supporting Information}

Contents

I. Experimental Procedures and Compound Characterization...................S2

II. $\quad{ }^{1} \mathrm{H}$ NMR and ${ }^{13} \mathrm{C}$ NMR Spectra for Compounds 3, 14, 15, 17, 18-22, 24, 26, 29,

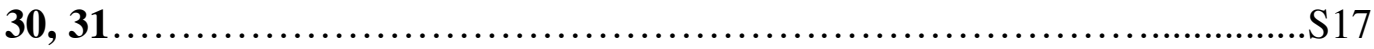

III. X-ray crystallography data for Compound $\mathbf{3}$ (CIF attached as separate file).....S50 


\section{Experimental Procedures and Compound Characterization}

General Experimental Methods. ${ }^{1} \mathrm{H}$ NMR spectra were recorded at ambient temperature at 400 and $500 \mathrm{MHz} .{ }^{13} \mathrm{C}$ NMR spectra were recorded at ambient temperature at 100 and $125 \mathrm{MHz}$. For ${ }^{1} \mathrm{H}$ NMR spectra acquired in $\mathrm{CDCl}_{3}$, chemical shifts are reported as $\delta$ values in ppm and are calibrated according to internal $\mathrm{CHCl}_{3}(7.26 \mathrm{ppm})$. For ${ }^{1} \mathrm{H}$ NMR spectra acquired in DMSO- $d_{6}$, chemical shifts are reported as $\delta$ values in ppm and are calibrated according to internal DMSO (2.50 ppm). For ${ }^{13} \mathrm{C}$ NMR spectra, chemical shifts are reported as $\delta$ values in ppm relative to chloroform or DMSO. The data are reported as follows: chemical shift in ppm on the $\delta$ scale, multiplicity $(\mathrm{app}=$ apparent, $\mathrm{br}=$ broad, $\mathrm{s}=$ singlet, $\mathrm{d}=$ doublet, $\mathrm{t}=$ triplet, $\mathrm{q}=$ quartet, $\mathrm{m}=$ multiplet, coupling constants $(\mathrm{Hz})$, and integration. Infrared spectra (IR) were obtained on a FTIR spectrophotometer and are reported in wavenumbers $\left(\mathrm{cm}^{-1}\right)$. Optical rotations were obtained with a digital polarimeter. Melting points (mp) were obtained from a melting-point apparatus and are reported uncorrected. High resolution mass spectra were acquired on an analytical CI, EI or ESI spectrometer and were obtained by peak matching.

Analytical thin-layer chromatography (TLC) was performed using $0.25 \mathrm{~mm}$ precoated silica gel plates. Liquid chromatography was performed using forced flow (flash chromatography) of the indicated solvent system on silica gel $\left(\mathrm{SiO}_{2}\right) 60(200-400)$ mesh. Reverse phase analytical HPLC was performed on a binary gradient LCMS System using a $\mathrm{C}_{18} 5 \mu \mathrm{m}(50 \mathrm{x}$ $4.6 \mathrm{~mm}$ ) column and a photodiode array detector and an electrospray ionization detector. Reverse phase preparative HPLC was performed on a binary gradient LCMS System using a $\mathrm{C}_{18}$ $5 \mu \mathrm{m}(50 \times 20 \mathrm{~mm})$ column and a photodiode array detector and an electrospray ionization detector. 
All reactions were carried out using flame-dried or oven-dried glassware and inert atmosphere operations were conducted under nitrogen passed through three drying tubes. Anhydrous tetrahydrofuran (THF), methylene chloride $\left(\mathrm{CH}_{2} \mathrm{Cl}_{2}\right)$, and $N, N$-dimethylformamide $(\mathrm{DMF})$, and diethyl ether $\left(\mathrm{Et}_{2} \mathrm{O}\right)$ were filtered through two columns of activated basic alumina and transferred under $\operatorname{Ar}(\mathrm{g})$ according to the method described by Grubbs. ${ }^{1}$ Triethylamine, $N, N-$ dimethylpropyleneurea, hexamethyldisilazane, and methanol were dried by distillation from calcium hydride under nitrogen. $\mathrm{BF}_{3} \cdot \mathrm{OEt}_{2}$ was distilled from $\mathrm{CaH}_{2}$ under reduced pressure prior to use. Concentrations of organolithium reagents were established by titration in $\mathrm{THF}$ at $0{ }^{\circ} \mathrm{C}$ against 3,5-di-tert-butyl-4-hydroxytoluene/1,10-phenanthroline. $\quad N$-Bromosuccinimde was recrystallized from water prior to use. All other commercial reagents were used as received and purchased unless otherwise noted.

\section{Experimental Procedures and Compound Characterization}

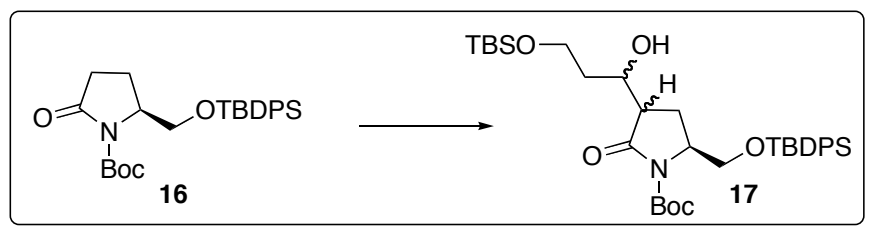

Aldol Products (17): To a cooled $\left(-78^{\circ} \mathrm{C}\right)$ solution of LiHMDS $(17.3 \mathrm{~mL}, 12.1 \mathrm{mmol}, 0.70 \mathrm{M}$ in THF) was added a solution of pyroglutamate $16(5.01 \mathrm{~g}, 11.0 \mathrm{mmol})$ in $\mathrm{THF}(50 \mathrm{~mL})$ dropwise via cannula. After $1 \mathrm{~h}$, a cooled $\left(-78 \quad{ }^{\circ} \mathrm{C}\right)$ solution of 3- $(t-$ butyldimethylsilyloxy)propanal $(2.70 \mathrm{~g}, 14.4 \mathrm{mmol})$ and $\mathrm{BF}_{3} \cdot \mathrm{OEt}_{2}(1.40 \mathrm{~mL}, 11.0 \mathrm{mmol})$ in $\mathrm{THF}$

\footnotetext{
${ }^{1}$ Pangborn, A.B.; Giardello, M.A.; Grubbs, R.H.; Rosen, R.K.; Timmers, F.J. Organometallics 1996, 15, 1518 1520.
} 
$(30 \mathrm{~mL})$ was added via cannula. The reaction mixture was stirred for $40 \mathrm{~min}$ at $-78{ }^{\circ} \mathrm{C}$. Saturated aqueous $\mathrm{NH}_{4} \mathrm{Cl}(25 \mathrm{~mL})$ was added and the mixture was warmed to room temperature. Water (15 $\mathrm{mL})$ was added and the aqueous layer was extracted with $\mathrm{Et}_{2} \mathrm{O}(3 \times 30 \mathrm{~mL})$. The combined organic layers were washed with $1 \mathrm{M} \mathrm{HCl}(30 \mathrm{~mL})$, brine $(35 \mathrm{~mL})$, saturated aqueous $\mathrm{NaHSO}_{3}(3$ x $30 \mathrm{~mL})$, dried $\left(\mathrm{MgSO}_{4}\right)$ and concentrated in vacuo to afford an orange oil. The crude oil was purified by flash chromatography (10:90 EtOAc/hexanes - 20:80 EtOAc/hexanes) to afford the product as a thick clear oil $(6.83 \mathrm{~g}, 96 \%)$. The product was isolated as a mixture of diastereomers that were used in the subsequent transformation without separation. A separated sample of one aldol diastereomer was obtained for characterization purposes: ${ }^{1} \mathrm{H}$ NMR $\left(500 \mathrm{MHz}, \mathrm{CDCl}_{3}\right) \delta$ 7.64-7.58 (m, 4H), 7.45-7.35 (m, 6H), $4.37(\mathrm{dt}, J=8.9,3.5,1 \mathrm{H}), 4.18(\mathrm{dt}, J=6.1,3.1,1 \mathrm{H}), 3.90$ $(\mathrm{dd}, J=10.5,4.1,2 \mathrm{H}), 3.87-3.83(\mathrm{~m}, 1 \mathrm{H}), 3.70(\mathrm{dd}, J=10.5,2.4,1 \mathrm{H}), 3.29$ (br s, $1 \mathrm{H}), 2.90$ $(\mathrm{ddd}, J=11.2,9.1,3.7,1 \mathrm{H}), 2.35(\mathrm{~m}, 1 \mathrm{H}), 2.07(\mathrm{dd}, J=12.5,9.3,1 \mathrm{H}), 1.78-1.68(\mathrm{~m}, 2 \mathrm{H}), 1.43$ (s, 9H), $1.04(\mathrm{~s}, 9 \mathrm{H}), 0.89(\mathrm{~s}, 9 \mathrm{H}), 0.08(\mathrm{~s}, 6 \mathrm{H}) ;{ }^{13} \mathrm{C} \mathrm{NMR}\left(125 \mathrm{MHz}, \mathrm{CDCl}_{3}\right) \delta$ 175.3, 150.2, $135.9,135.8,133.5,133.1,130.3,130.1,128.3,128.2,83.1,69.9,65.5,62.8,57.4,49.4,36.8$, 28.5, 27.2, 26.3, 22.2, 19.6, 18.6, -5.0; IR (thin film) 3488, 3071, 2948, 2853, 1779, 1721, 1469, 1364, $1153 \mathrm{~cm}^{-1}$; HRMS (CI/methanol) $m / z$ calcd for $\mathrm{C}_{35} \mathrm{H}_{55} \mathrm{NO}_{6} \mathrm{Si}_{2}(\mathrm{M}+\mathrm{Na})^{+} 664.3466$, found $664.3465 ;[\alpha]^{24}-28.8^{\circ}\left(c 0.32, \mathrm{CHCl}_{3}\right)$. 


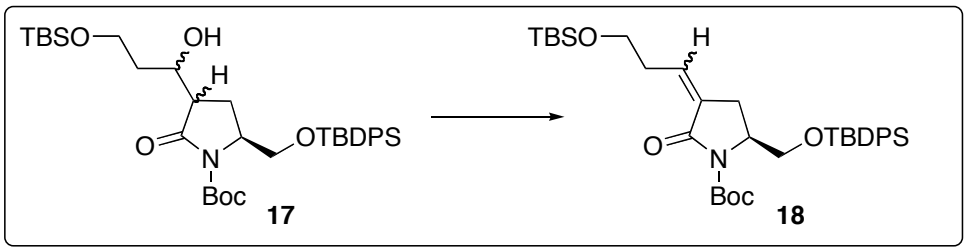

Alkene (18): To a cooled $\left(0{ }^{\circ} \mathrm{C}\right)$ solution of alcohol $17(8.13 \mathrm{~g}, 12.7 \mathrm{mmol})$ in $\mathrm{CH}_{2} \mathrm{Cl}_{2}(60 \mathrm{~mL})$ was added imidazole $\left(2.59 \mathrm{~g}, 38.0 \mathrm{mmol}, \mathrm{Ph}_{3} \mathrm{P}(3.66 \mathrm{~g}, 13.9 \mathrm{mmol})\right.$, and iodine $(3.54 \mathrm{~g}, 13.9$ $\mathrm{mmol})$. The red/orange reaction mixture was slowly warmed to room temperature and stirred for $8 \mathrm{~h}$, during which time a yellow precipitate $\left(\mathrm{Ph}_{3} \mathrm{P}=\mathrm{O}\right)$ forms. The reaction was quenched by the addition of saturated aqueous $\mathrm{Na}_{2} \mathrm{~S}_{2} \mathrm{O}_{3}(40 \mathrm{~mL})$. The resultant colorless solution was diluted with water $(20 \mathrm{~mL})$ and the aqueous layer was extracted with $\mathrm{CH}_{2} \mathrm{Cl}_{2}(3 \mathrm{x} 40 \mathrm{~mL})$. The combined organic extracts were washed with brine $(100 \mathrm{~mL})$, dried $\left(\mathrm{Na}_{2} \mathrm{SO}_{4}\right)$ and concentrated in vacuo to provide an orange oil. ${ }^{1} \mathrm{H}$ NMR analysis of the crude reaction mixture revealed that the $(E)$ and (Z) alkene isomers were formed in a ratio of 5:1, respectively. The crude oil was purified by flash chromatography (5:95 EtOAc/hexanes) to afford $\mathbf{1 8}$ as a yellow oil (7.51 g, 95\%). Separated samples of $(E)-\mathbf{1 8}$ and $(Z)-\mathbf{1 8}$ were obtained for characterization purposes:

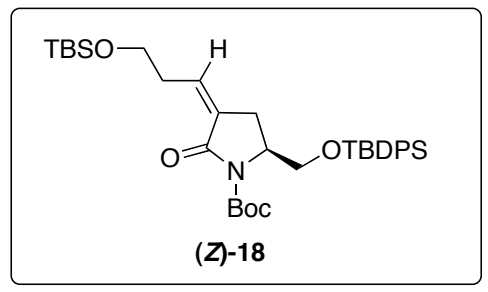

(Z)-18: ${ }^{1} \mathrm{H}$ NMR $\left(500 \mathrm{MHz}, \mathrm{CDCl}_{3}\right) \delta 7.64-7.58(\mathrm{~m}, 4 \mathrm{H}), 7.44-7.35(\mathrm{~m}, 6 \mathrm{H}), 6.17($ app $\mathrm{t}, J=$ 7.3, 1H), $4.18(\mathrm{~m}, 1 \mathrm{H}), 3.82(\mathrm{dd}, J=10.2,4.7,1 \mathrm{H}), 3.70-3.67(\mathrm{~m}, 3 \mathrm{H}), 3.11-3.06(\mathrm{~m}, 1 \mathrm{H}), 2.79-$ 
$2.91(\mathrm{~m}, 2 \mathrm{H}), 2.70(\mathrm{~d}, J=15.9,1 \mathrm{H}), 1.47(\mathrm{~s}, 9 \mathrm{H}), 1.05(\mathrm{~s}, 9 \mathrm{H}), 0.88(\mathrm{~s}, 9 \mathrm{H}), 0.06(\mathrm{~s}, 6 \mathrm{H}) ;{ }^{13} \mathrm{C}$ NMR (125 MHz, $\left.\mathrm{CDCl}_{3}\right) \delta 167.3,151.1,138.7,138.2,136.1,136.0,133.7,133.3,130.5,130.2$, $128.2,128.1,82.9,65.1,62.8,56.0,31.3,29.6,28.5,27.1,26.4,19.7,18.8,-4.8$; IR (thin film) 3071, 2962, 2928, 1775, 1734, 1666, 1364, 1303, $1157 \mathrm{~cm}^{-1}$; HRMS (CI/methanol) $\mathrm{m} / \mathrm{z}$ calcd for $\mathrm{C}_{35} \mathrm{H}_{53} \mathrm{NO}_{5} \mathrm{Si}_{2}(\mathrm{M}+\mathrm{Na})^{+} 646.3360$, found 646.3354; $[\alpha]^{24}{ }_{\mathrm{D}}-26.1^{\circ}\left(c 0.25, \mathrm{CHCl}_{3}\right)$.

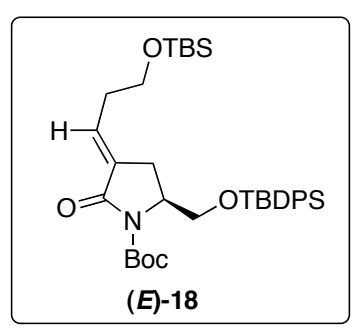

(E)-18: ${ }^{1} \mathrm{H}$ NMR $\left(500 \mathrm{MHz}, \mathrm{CDCl}_{3}\right) \delta$ 7.63-7.57 (m, 4H), 7.44-7.35 (m, 6H), 6.68 (ddd, $J=$ $10.1,7.3,2.7,1 \mathrm{H}), 4.26(\mathrm{~m}, 1 \mathrm{H}), 3.85(\mathrm{dd}, J=10.3,4.2,1 \mathrm{H}), 3.75-3.67(\mathrm{~m}, 3 \mathrm{H}), 2.78-2.68(\mathrm{~m}$, 2H), $2.41(\mathrm{dd}, J=14.0,7.0,2 \mathrm{H}), 1.46(\mathrm{~s}, 9 \mathrm{H}), 1.00(\mathrm{~s}, 9 \mathrm{H}), 0.90(\mathrm{~s}, 9 \mathrm{H}), 0.06(\mathrm{~d}, J=1.9,6 \mathrm{H})$; ${ }^{13} \mathrm{C}$ NMR $\left(125 \mathrm{MHz}, \mathrm{CDCl}_{3}\right) \delta 167.2,150.9,136.0,135.9,133.7,133.6,133.2,133.1,130.2$, $130.1,128.2,128.1,83.0,65.2,61.9,56.1,33.7,28.5,27.1,26.4,25.9,19.7,18.7,-4.9$; IR (thin film) 3043, 2986, 2920, 1777, 1750, 1707, 1469, 1364, 1249, $1109 \mathrm{~cm}^{-1}$; HRMS (CI/methanol) $m$ / $z$ calcd for $\mathrm{C}_{35} \mathrm{H}_{53} \mathrm{NO}_{5} \mathrm{Si}_{2}(\mathrm{M}+\mathrm{Na})^{+}$646.3360, found 646.3357; $[\alpha]^{24}{ }_{\mathrm{D}}-4.2^{\circ}\left(c 0.15, \mathrm{CHCl}_{3}\right)$. 


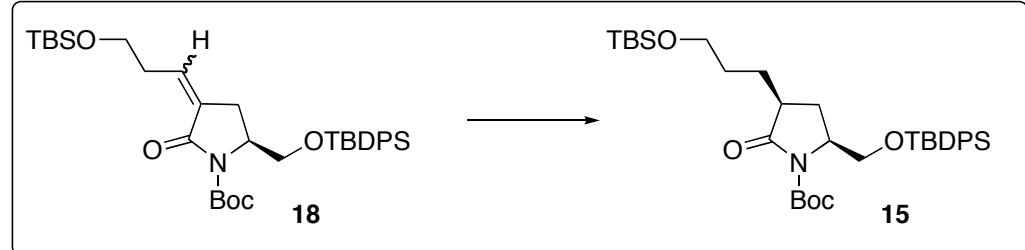

3,5-Disubstituted Pyrrolidine (15): To a solution of alkene 18 (3.93 g, $6.31 \mathrm{mmol}$ ) in anhydrous EtOAc $(32 \mathrm{~mL})$ under a $\mathrm{N}_{2}$ atmosphere was added 10\% $\mathrm{Pd} / \mathrm{C}(0.672 \mathrm{~g}, 0.631 \mathrm{mmol})$. The $\mathrm{N}_{2}$ atmosphere was replaced with an atmosphere of $\mathrm{H}_{2}$. After $24 \mathrm{~h}$, the flask was evacuated under vacuum and purged with $\mathrm{N}_{2}$. The crude reaction mixture was filtered through a pad of Celite and washed with EtOAc $(3 \times 30 \mathrm{~mL})$. Concentration in vacuo provided a colorless oil that was purified by flash chromatography (10:90 -15:85 EtOAc/hexanes) to afford $\mathbf{1 5}$ as a clear oil

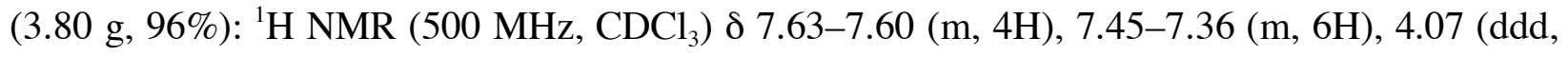
$J=12.2,8.3,2.7,1 \mathrm{H}), 3.88(\mathrm{dd}, J=10.1,5.5,1 \mathrm{H}), 3.78(\mathrm{dd}, J=10.1,2.7,1 \mathrm{H}), 3.61(\mathrm{~m}, 2 \mathrm{H})$, $2.50(\mathrm{qd}, J=4.8,18.7,1 \mathrm{H}), 2.28(\mathrm{ddd}, J=13.0,10.1,8.3,1 \mathrm{H}), 1.94(\mathrm{~m}, 1 \mathrm{H}), 1.83(\mathrm{ddd}, J=$ $13.1,8.7,6.8,1 \mathrm{H}), 1.66-1.57(\mathrm{~m}, 3 \mathrm{H}), 1.42(\mathrm{~s}, 9 \mathrm{H}), 1.04(\mathrm{~s}, 9 \mathrm{H}), 0.88(\mathrm{~s}, 9 \mathrm{H}), 0.04(\mathrm{~s}, 6 \mathrm{H}) ;{ }^{13} \mathrm{C}$ NMR (125 MHz, $\left.\mathrm{CDCl}_{3}\right) \delta 176.9,150.7,136.1,136.0,133.7,133.4,130.2,130.1,128.2,128.1$, $83.1,64.6,63.4,57.3,42.7,31.1,28.6,28.4,27.3,26.7,26.4,19.7,18.8,-4.8$; IR (thin film) 3071, 2948, 2860, 1785, 1748, 1473, 1367, 1303, $1116 \mathrm{~cm}^{-1}$; HRMS (CI/methanol) $\mathrm{m} / \mathrm{z}$ calcd for $\mathrm{C}_{35} \mathrm{H}_{55} \mathrm{NO}_{5} \mathrm{Si}_{2}(\mathrm{M}+\mathrm{Na})^{+} 648.3516$, found 648.3541; $[\alpha]^{24}-16.6^{\circ}\left(c 0.27, \mathrm{CHCl}_{3}\right)$. 


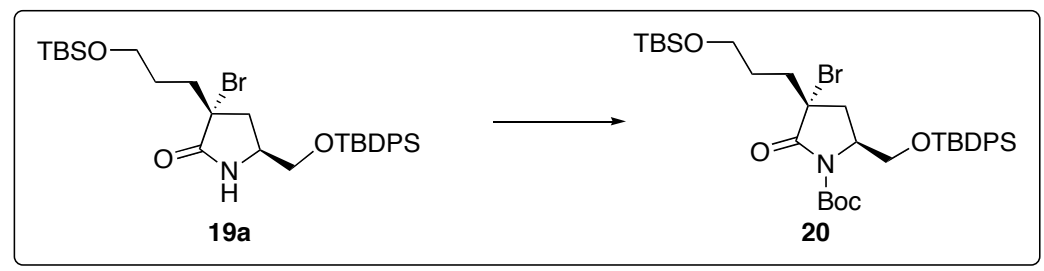

$N$-Boc Bromo Lactam (20): A cooled $\left(0{ }^{\circ} \mathrm{C}\right)$ solution of 19a $(2.45 \mathrm{~g}, 4.05 \mathrm{mmol})$ in $\mathrm{CH}_{2} \mathrm{Cl}_{2}(20$ $\mathrm{mL})$ was treated sequentially with $\mathrm{Et}_{3} \mathrm{~N}(1.70 \mathrm{~mL}, 12.1 \mathrm{mmol})$, DMAP (0.494 $\left.\mathrm{g}, 4.05 \mathrm{mmol}\right)$, and $\mathrm{Boc}_{2} \mathrm{O}(1.30 \mathrm{~g}, 6.07 \mathrm{mmol})$. The clear orange solution was warmed to room temperature and stirred for $3 \mathrm{~h}$. The reaction mixture was diluted with water $(10 \mathrm{~mL})$ and the layers were separated. The aqueous layer was extracted with $\mathrm{CH}_{2} \mathrm{Cl}_{2}(3 \times 15 \mathrm{~mL})$ and the combined organic layers were washed with $1.0 \mathrm{M} \mathrm{HCl}(8 \mathrm{~mL})$, dried $\left(\mathrm{MgSO}_{4}\right)$, and concentrated in vacuo to afford an orange oil. Purification of the crude oil by flash chromatography (5:95 EtOAc/hexanes) afforded the title compound as a clear oil $(2.80 \mathrm{~g}, 98 \%):{ }^{1} \mathrm{H} \mathrm{NMR}\left(500 \mathrm{MHz}, \mathrm{CDCl}_{3}\right) \delta 7.61-$ $7.58(\mathrm{~m}, 4 \mathrm{H}), 7.45-7.36(\mathrm{~m}, 6 \mathrm{H}), 4.20(\mathrm{dd}, J=10.5,4.4,1 \mathrm{H}), 4.16-4.13(\mathrm{~m}, 1 \mathrm{H}), 3.74(\mathrm{dd}, J=$ $10.5,2.1,1 \mathrm{H}), 3.71-3.64(\mathrm{~m}, 2 \mathrm{H}), 2.42(\mathrm{dd}, J=14.7,6.4,1 \mathrm{H}), 2.34-2.37(\mathrm{dd}, J=14.6,2.9,1 \mathrm{H}$ and $\mathrm{m}, 1 \mathrm{H}), 1.94(\mathrm{td}, J=11.7,4.0,1 \mathrm{H}), 1.90-1.81(\mathrm{~m}, 1 \mathrm{H}), 1.64-1.56(\mathrm{~m}, 1 \mathrm{H}), 1.48(\mathrm{~s}, 9 \mathrm{H})$, $1.04(\mathrm{~s}, 9 \mathrm{H}), 0.90(\mathrm{~s}, 9 \mathrm{H}), 0.06(\mathrm{~d}, J=2.8,6 \mathrm{H}) ;{ }^{13} \mathrm{C} \mathrm{NMR}\left(125 \mathrm{MHz}, \mathrm{CDCl}_{3}\right) \delta$ 171.6, 150.7, $136.0,135.9,133.4,133.2,130.3,130.2,128.2,128.1,84.0,64.8,62.9,62.5,56.3,37.1,36.0$, 29.5, 28.4, 27.2, 26.4, 19.7, 18.8, -4.9; IR (thin film) 3064, 2935, 1789, 1755, 1724, 1588, 1473, 1361, $1113 \mathrm{~cm}^{-1}$; HRMS (CI/methanol) $m / z$ calcd for $\mathrm{C}_{35} \mathrm{H}_{54} \mathrm{BrNO}_{5} \mathrm{Si}_{2}(\mathrm{M}+\mathrm{Na})^{+} 726.2621$, found $726.2615 ;[\alpha]^{24}{ }_{D}-51.9^{\circ}\left(c 0.55, \mathrm{CHCl}_{3}\right)$. 


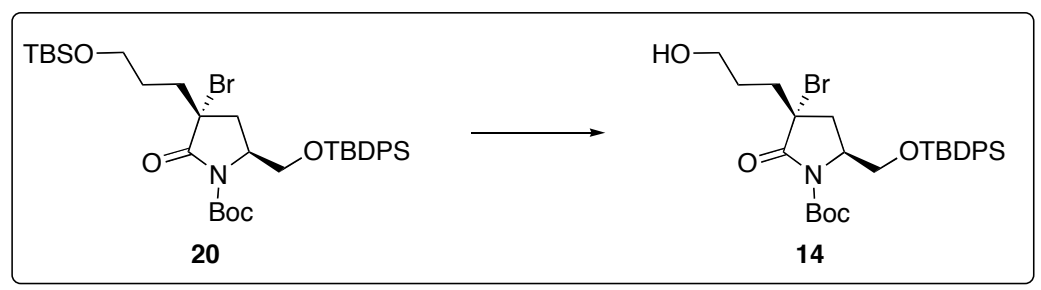

Alcohol (14): To a solution of 20 (2.80 g, $3.97 \mathrm{mmol})$ in $\left.\mathrm{THF} / \mathrm{H}_{2} \mathrm{O}(40 \mathrm{~mL} / 2 \mathrm{~mL})\right)$ was added TsOH (0.076 g, $0.397 \mathrm{mmol})$. The clear, colorless solution was stirred at room temperature for $24 \mathrm{~h}$ before additional $\mathrm{TsOH}(0.076 \mathrm{~g}, 0.397 \mathrm{mmol})$ was added. After $2 \mathrm{~h}$, the reaction was quenched by the addition of $\mathrm{Et}_{3} \mathrm{~N}(2 \mathrm{~mL})$. The solution was concentrated in vacuo to produce a crude oil that was purified by flash chromatography (30:70 EtOAc/hexanes) to afford alcohol 14 as a white foam $(2.16 \mathrm{~g}, 93 \%):{ }^{1} \mathrm{H}$ NMR $\left(500 \mathrm{MHz}, \mathrm{CDCl}_{3}\right) \delta 7.60-7.59(\mathrm{~m}, 4 \mathrm{H}), 7.45-7.37$ (m, $6 \mathrm{H}), 4.22-4.14(\mathrm{dd}, J=10.4,4.4,1 \mathrm{H}$ and $\mathrm{m}, 1 \mathrm{H}), 3.76(\mathrm{dd}, J=10.4,1.9,1 \mathrm{H}), 3.68(\mathrm{td}, J=6.3$, 2.0, 2H), $2.42(\mathrm{dd}, J=14.8,6.4,1 \mathrm{H}), 2.37-2.28(\mathrm{dd}, J=14.7,8.5,1 \mathrm{H}$ and $\mathrm{m}, 1 \mathrm{H}), 2.01(\mathrm{td}, J=$ 11.3, 4.6, 1H), 1.93-1.85 (m, 1H), 1.73 (br s, 1H), 1.68-1.59 (m, 1H), $1.46(\mathrm{~s}, 9 \mathrm{H}), 1.04(\mathrm{~s}, 9 \mathrm{H})$; ${ }^{13} \mathrm{C}$ NMR $\left(125 \mathrm{MHz}, \mathrm{CDCl}_{3}\right) \delta 171.8,150.6,136.0,135.9,133.5,133.2,130.4,130.2,128.4$, 128.3, 84.2, 64.4, 62.7, 62.4, 56.4, 36.9, 35.7, 29.3, 28.4, 27.3, 19.8; IR (thin film) 3494, 2935, 2860, 1785, 1755, 1724, 1588, 1469, 1357, $1150 \mathrm{~cm}^{-1}$; HRMS (CI/methanol) $m / z$ calcd for $\mathrm{C}_{29} \mathrm{H}_{40} \mathrm{BrNO}_{5} \mathrm{Si}(\mathrm{M}+\mathrm{Na})^{+} 612.1757$, found 612.1745; $[\alpha]^{24}-62.9^{\circ}\left(c 0.19, \mathrm{CHCl}_{3}\right)$. 


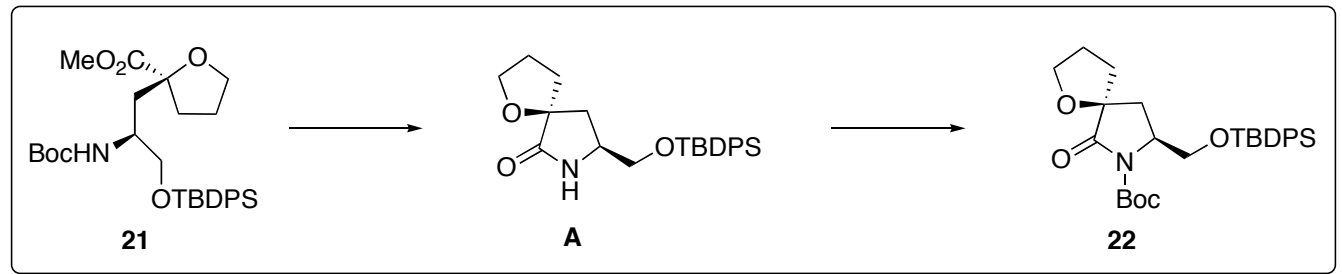

Spirolactam (22): To a cooled $\left(0^{\circ} \mathrm{C}\right)$ solution of $\mathrm{KO}^{t} \mathrm{Bu}(0.073 \mathrm{~g}, 0.647 \mathrm{mmol})$ in $\mathrm{THF}(5 \mathrm{~mL})$ was added a solution of oxolane $21(0.319 \mathrm{~g}, 0.588 \mathrm{mmol})$ in THF $(6 \mathrm{~mL})$ dropwise via cannula over $3 \mathrm{~min}$. The cloudy red reaction mixture was stirred for $30 \mathrm{~min}$ at $0{ }^{\circ} \mathrm{C}$. The reaction was quenched by the dropwise addition of $\mathrm{AcOH}$ until the $\mathrm{pH}$ is no longer basic and slightly acidic. The solution is then neutralized by the addition of saturated aqueous $\mathrm{NaHCO}_{3}(3 \mathrm{~mL})$ and diluted with $\mathrm{H}_{2} \mathrm{O}(5 \mathrm{~mL})$. The aqueous layer was extracted with EtOAc $(3 \times 5 \mathrm{~mL})$ and the combined organic layers were washed with brine, dried $\left(\mathrm{MgSO}_{4}\right)$, and concentrated in vacuo. The crude oil was purified by flash chromatography (45:55 EtOAc/hexanes) to afford lactam $\mathbf{A}$ as a clear oil (0.204 g, 85\%): ${ }^{1} \mathrm{H}$ NMR (500 MHz, $\left.\mathrm{CDCl}_{3}\right) \delta$ 7.66-7.61 (m, 4H), 7.46-7.37 (m, 6H), 6.33 (br s, 1H), 4.06-4.00 (m, 1H), 3.95-3.90 (m, 1H), 3.69-3.63 (m, 2H), 3.59-3.56 (m, 1H), 2.24-2.13 $(\mathrm{m}, 2 \mathrm{H}), 2.09(\mathrm{dd}, J=13.2,6.4,1 \mathrm{H}), 1.97-1.89(\mathrm{~m}, 1 \mathrm{H}), 1.87-1.80(\mathrm{dd}, J=13.2,6.1,1 \mathrm{H}$ and $\mathrm{m}$, 1H), $1.04(\mathrm{~s}, 9 \mathrm{H}) ;{ }^{13} \mathrm{C} \mathrm{NMR}\left(125 \mathrm{MHz}, \mathrm{CDCl}_{3}\right) \delta 178.3,136.0,135.9,133.5,133.3,130.3,130.2$, 128.3, 128.2, 84.1, 69.9, 68.0, 52.6, 37.4, 35.0, 27.2, 26.4, 19.6; IR (thin film) 3212, 2927, 2862, 1712, 1430, $1112 \mathrm{~cm}^{-1}$; HRMS (CI/methanol) $m / z$ calcd for $\mathrm{C}_{24} \mathrm{H}_{31} \mathrm{NO}_{3} \mathrm{Si}(\mathrm{M}+\mathrm{H})^{+} 410.2151$, found 410.2143; $[\alpha]^{24}+3.2^{\circ}\left(c 0.75, \mathrm{CHCl}_{3}\right)$.

To a cooled $\left(0{ }^{\circ} \mathrm{C}\right)$ solution of lactam $\mathbf{A}(0.342 \mathrm{~g}, 0.836 \mathrm{mmol})$ in $\mathrm{CH}_{2} \mathrm{Cl}_{2}(8 \mathrm{~mL})$ were added $\mathrm{Et}_{3} \mathrm{~N}(0.350 \mathrm{~mL}, 2.51 \mathrm{mmol})$, DMAP (0.102 g, $\left.0.836 \mathrm{mmol}\right)$, and $\mathrm{Boc}_{2} \mathrm{O}(0.273 \mathrm{~g}, 1.25 \mathrm{mmol})$. 
The clear yellow solution was allowed to warm to room temperature and was stirred overnight. The reaction mixture was diluted with $\mathrm{H}_{2} \mathrm{O}(8 \mathrm{~mL})$ and the aqueous layer was extracted with $\mathrm{CH}_{2} \mathrm{Cl}_{2}(3 \times 8 \mathrm{~mL})$. The organic layer was washed with $1 \mathrm{M} \mathrm{HCl}(8 \mathrm{~mL})$, brine $(10 \mathrm{~mL})$, dried $\left(\mathrm{MgSO}_{4}\right)$, and concentrated in vacuo. Purification of the crude yellow oil by flash chromatography afforded the title compound 22 as a white solid $(0.341 \mathrm{~g}, 80 \%)$ : $\mathrm{mp}=104-107$ ${ }^{\circ} \mathrm{C} ;{ }^{1} \mathrm{H}$ NMR (500 MHz, $\left.\mathrm{CDCl}_{3}\right) \delta$ 7.68-7.65 (m, 4H), 7.43-7.35 (m, 6H), 4.16-4.11 (m, 1H), $3.98-3.91(\mathrm{~m}, 3 \mathrm{H}), 3.86($ app t, $J=9.1,1 \mathrm{H}), 2.42(\mathrm{dd}, J=13.9,2.5,1 \mathrm{H}), 2.32(\mathrm{ddd}, J=12.5$, $8.3,5.9,1 \mathrm{H}), 2.20(\mathrm{ddd}, J=18.9,12.5,6.5,1 \mathrm{H}), 2.10(\mathrm{dd}, J=13.9,7.9,1 \mathrm{H}), 1.99-1.91(\mathrm{~m}, 1 \mathrm{H})$, $1.79(\mathrm{ddd}, J=12.5,8.8,6.5,1 \mathrm{H}), 1.42(\mathrm{~s}, 9 \mathrm{H}), 1.06(\mathrm{~s}, 9 \mathrm{H}) ;{ }^{13} \mathrm{C} \mathrm{NMR}\left(125 \mathrm{MHz}, \mathrm{CDCl}_{3}\right) \delta$ 174.5, 149.9, 135.7, 135.6, 133.5, 133.3, 129.7, 129.4, 127.7, 127.6, 84.5, 83.0, 69.3, 64.0, 56.0, 34.0, 33.5, 27.9, 26.8, 25.9, 19.4; IR (KBr) 2975, 2927, 1763, 1720, 1615, 1309, $1163 \mathrm{~cm}^{-1}$; HRMS $\left(\mathrm{CI} /\right.$ methanol) $m / z$ calcd for $\mathrm{C}_{29} \mathrm{H}_{39} \mathrm{NO}_{5} \mathrm{Si}(\mathrm{M}+\mathrm{Na})^{+} 532.2495$, found 532.2474; $[\alpha]^{24}{ }_{\mathrm{D}}$ $-37.7^{\circ}\left(c 0.14, \mathrm{CHCl}_{3}\right)$.

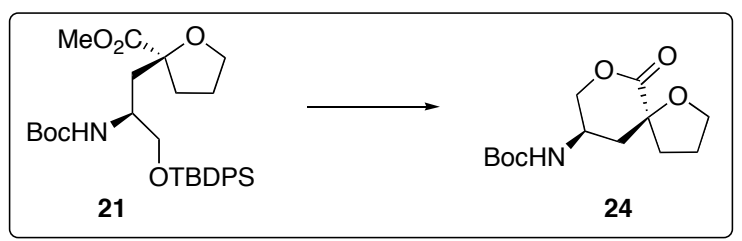

Lactone (24): To a solution of oxolane $21(0.103 \mathrm{~g}, 0.189 \mathrm{mmol})$ in DMF (3 mL) at room temperature were added $\mathrm{AcOH}(0.01 \mathrm{~mL}, 0.189 \mathrm{mmol})$ and TBAF $(0.20 \mathrm{~mL}, 0.208 \mathrm{mmol}, 1.0 \mathrm{M}$ in THF). The clear, colorless solution was stirred for $30 \mathrm{~h}$ at room temperature. Saturated aqueous $\mathrm{NaHCO}_{3}(1 \mathrm{~mL})$ was added and the reaction mixture was diluted with EtOAc $(3 \mathrm{~mL})$ and $\mathrm{H}_{2} \mathrm{O}(3 \mathrm{~mL})$. The aqueous layer was extracted with EtOAc $(3 \times 5 \mathrm{~mL})$ and the combined 
organic layers were washed with saturated aqueous $\mathrm{NH}_{4} \mathrm{Cl}(2 \times 5 \mathrm{~mL})$, brine $(8 \mathrm{~mL})$, dried $\left(\mathrm{MgSO}_{4}\right)$ and concentrated in vacuo. The crude solid was purified by flash chromatography (20:80 EtOAc/hexanes-50:50 EtOAc/Hex) to afford lactone $24(0.020 \mathrm{~g})$ as a white solid and alcohol $23(0.020 \mathrm{~g})$ as a clear oil $(0.040 \mathrm{~g}, 73 \%)$. Alcohol $23(0.020 \mathrm{~g}, 0.066 \mathrm{mmol})$ was dissolved in $\mathrm{CH}_{2} \mathrm{Cl}_{2}$ and PPTS ( $2 \mathrm{mg}$ ) was added. After $20 \mathrm{~h}$, the solution was neutralized by the addition of $\mathrm{Et}_{3} \mathrm{~N}(0.3 \mathrm{~mL})$ and concentrated in vacuo to afford a yellow oil. Purification of the crude oil by flash chromatography (20:80 EtOAc/hexanes) afforded lactone $\mathbf{2 4}$ as a white solid $(0.013 \mathrm{~g}, 75 \%):{ }^{1} \mathrm{H}$ NMR (500 MHz, DMSO- $\left.d_{6},\right) \delta 7.16(\mathrm{~d}, J=6.6,1 \mathrm{H}), 4.34(\mathrm{dd}, J=10.3,3.6$, 1H), 4.05-3.95 (m, 2H), $3.87(\mathrm{dd}, J=15.1,7.4,1 \mathrm{H}), 3.72(\mathrm{dd}, J=14.9,7.2,1 \mathrm{H}), 2.38-2.32(\mathrm{~m}$, $1 \mathrm{H}), 2.16(\mathrm{dd}, J=6.0,1.4,1 \mathrm{H}), 2.02-1.92(\mathrm{dd}, J=14.1,8.7,1 \mathrm{H}$ and $\mathrm{m}, 1 \mathrm{H}), 1.91-1.84(\mathrm{~m}, 1 \mathrm{H})$, $1.64(\mathrm{ddd}, J=12.7,8.8,7.1,1 \mathrm{H}), 1.38(\mathrm{~s}, 9 \mathrm{H}) ;{ }^{13} \mathrm{C}$ NMR $\left(125 \mathrm{MHz}, \mathrm{DMSO}-d_{6}\right) \delta 171.3,155.8$, 81.3, 79.1, 71.2, 69.2, 43.4, 38.8, 35.5, 29.0, 26.4; IR (thin film) 3378, 2989, 1745, 1683, 1510, 1371, $1170 \mathrm{~cm}^{-1}$; HRMS (CI/methanol) $m / z$ calcd for $\mathrm{C}_{13} \mathrm{H}_{21} \mathrm{NO}_{5}(\mathrm{M}+\mathrm{Na})^{+} 294.1317$, found 294.1310; $[\alpha]^{24}-77.5^{\circ}\left(c 0.17, \mathrm{CHCl}_{3}\right)$.

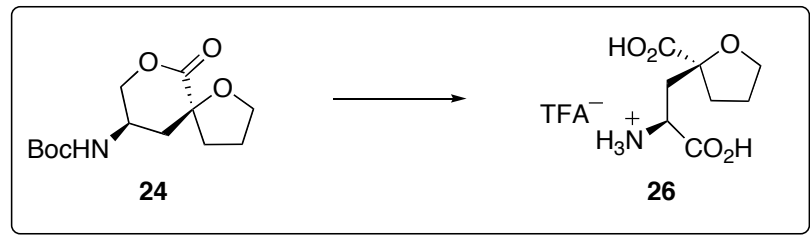

Deoxylycoperdic acid (26): To a cooled $\left(0^{\circ} \mathrm{C}\right)$ solution of lactone $24(0.050 \mathrm{~g}, 0.185 \mathrm{mmol})$ in acetone $(4 \mathrm{~mL})$ was added Jones reagent $\left(0.150 \mathrm{~mL}, 0.408 \mathrm{mmol}, 2.7 \mathrm{M} \mathrm{CrO}_{3}\right.$ in $\left.4 \mathrm{M} \mathrm{H}_{2} \mathrm{SO}_{4}\right)$. The red solution was slowly warmed to room temperature over $1 \mathrm{~h}$, during which a brown precipitate formed. After stirring for $2 \mathrm{~h}$ at room temperature, the brown reaction mixture was 
cooled to $0{ }^{\circ} \mathrm{C}$ and isopropanol $(1.0 \mathrm{~mL})$ was added. The resulting green reaction mixture was warmed to room temperature and stirred for $30 \mathrm{~min}$. The mixture was filtered through celite, the celite pad was washed with acetone $(3 \times 5 \mathrm{~mL})$, and the yellow filtrate was concentrated in vacuo to afford a brown oil. The crude oil was dissolved in $\mathrm{CH}_{2} \mathrm{Cl}_{2}$ and cooled to $0{ }^{\circ} \mathrm{C}$. TFA $(0.2 \mathrm{~mL})$ was added and the brown solution was warmed to room temperature. After $18 \mathrm{~h}$, the solution was concentrated in vacuo to afford a brown residue. Purification of the crude oil by reverse phase HPLC $\left(1 \% \mathrm{CH}_{3} \mathrm{CN} / 0.1 \%\right.$ aqueous TFA-2\% $\mathrm{CH}_{3} \mathrm{CN} / 0.1 \%$ aqueous TFA over $5 \mathrm{~min}$, then ramp to $95 \% \mathrm{CH}_{3} \mathrm{CN} / 0.1 \%$ aqueous TFA over $15 \mathrm{~min}$ ) gave the title compound as a white solid after lyophilization (0.030 g, 50\%): ${ }^{1} \mathrm{H}$ NMR (500 MHz, $\left.\mathrm{D}_{2} \mathrm{O}\right) \delta 4.04-3.96(\mathrm{~m}, 2 \mathrm{H}) ; 3.92(\mathrm{~d}, J=9.3$, $1 \mathrm{H}), 2.78(\mathrm{dd}, J=15.2,3.3,1 \mathrm{H}), 2.39-2.33(\mathrm{~m}, 1 \mathrm{H}), 2.15-2.05(\mathrm{dd}, J=15.2,10.1,1 \mathrm{H}$ and $\mathrm{m}$, 1H), 2.04-1.94 (m, 2H); ${ }^{13} \mathrm{C}$ NMR (125 MHz, D $\left.2 \mathrm{O}\right) \delta 178.13,172.4,85.7,70.4,52.1,37.6,37.3$, 24.9; HRMS (CI/methanol) $m / z$ calcd for $\mathrm{C}_{8} \mathrm{H}_{13} \mathrm{NO}_{5}(\mathrm{M}+\mathrm{Na})^{+}$204.0872, found 204.0874; $[\alpha]_{D}^{24}-41.9^{\circ}\left(c 0.34, \mathrm{H}_{2} \mathrm{O}\right)$.

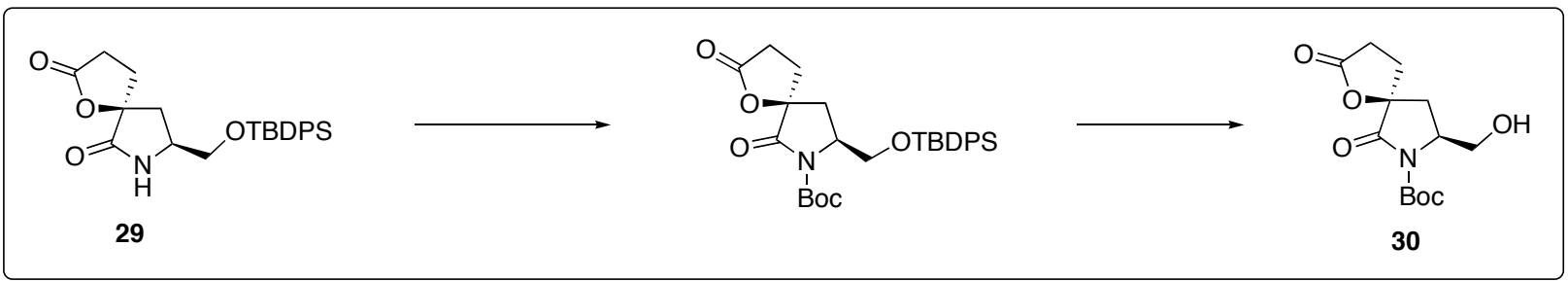

Pyroglutaminol (30): A cooled $\left(0{ }^{\circ} \mathrm{C}\right)$ solution of $29(0.903 \mathrm{~g}, 2.13 \mathrm{mmol})$ in $\mathrm{CH}_{2} \mathrm{Cl}_{2}(20 \mathrm{~mL})$ was treated sequentially with $\mathrm{Et}_{3} \mathrm{~N}(0.89 \mathrm{~mL}, 6.39 \mathrm{mmol})$, DMAP (0.260 g, $\left.2.13 \mathrm{mmol}\right)$, and $\mathrm{Boc}_{2} \mathrm{O}(0.698 \mathrm{~g}, 3.20 \mathrm{mmol})$. The clear yellow solution was warmed to room temperature and stirred for $2 \mathrm{~h}$. The reaction mixture was diluted with water $(15 \mathrm{~mL})$ and the layers were separated. The aqueous layer was extracted with $\mathrm{CH}_{2} \mathrm{Cl}_{2}(3 \times 15 \mathrm{~mL})$ and the combined organic 
layers were washed with $1.0 \mathrm{M} \mathrm{HCl}(15 \mathrm{~mL})$, dried $\left(\mathrm{MgSO}_{4}\right)$, and concentrated in vacuo to afford a yellow foam. Purification of the crude foam by flash chromatography (30:70 EtOAc/hexanes) afforded the $N$-Boc lactam as a white foam $(1.11 \mathrm{~g}, 90 \%): \mathrm{mp}=50-52{ }^{\circ} \mathrm{C} ;{ }^{1} \mathrm{H}$

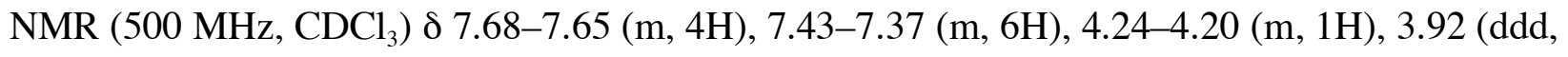
$J=9.8,3.8,1 \mathrm{H}), 3.82(\mathrm{dd}, J=9.6,8.3,1 \mathrm{H}), 2.99(\mathrm{dt}, J=17.8,10.7,1 \mathrm{H}), 2.70(\mathrm{dd}, J=2.0,14.6$, $1 \mathrm{H}), 2.61-2.52(\mathrm{~m}, 2 \mathrm{H}), 2.24(\mathrm{dd}, J=14.6,8.2,1 \mathrm{H}), 2.17-2.10(\mathrm{~m}, 1 \mathrm{H}), 1.41(\mathrm{~s}, 9 \mathrm{H}), 1.06(\mathrm{~s}$, $9 \mathrm{H}) ;{ }^{13} \mathrm{C} \mathrm{NMR}\left(125 \mathrm{MHz}, \mathrm{CDCl}_{3}\right) \delta 175.9,171.6,149.7,136.0,135.9,133.5,133.2,130.4$, $130.3,128.3,128.2,85.5,84.4,64.1,56.3,32.2,31.3,28.8,28.2,27.2,19.7$; IR (KBr) 2921, 2962, 2853, 1792, 1717, 1296, 1147, $1109 \mathrm{~cm}^{-1}$; HRMS (CI/methanol) $m / z$ calcd for $\mathrm{C}_{29} \mathrm{H}_{37} \mathrm{NO}_{6} \mathrm{Si}(\mathrm{M}+\mathrm{Na})^{+} 546.2288$, found 546.2275; $[\alpha]^{24}-37.7^{\circ}\left(c 0.20, \mathrm{CHCl}_{3}\right)$.

To a solution of the above $N$-Boc silyl ether $(1.05 \mathrm{~g}, 2.01 \mathrm{mmol})$ in DMF $(20 \mathrm{~mL})$ at room temperature were added $\mathrm{AcOH}(0.25 \mathrm{~mL}, 4.42 \mathrm{mmol})$ and TBAF $(2.4 \mathrm{~mL}, 2.41 \mathrm{mmol}, 1.0 \mathrm{M}$ in THF). The clear yellow solution was stirred for $8 \mathrm{~h}$ at room temperature. The reaction mixture was diluted with $\mathrm{H}_{2} \mathrm{O}(20 \mathrm{~mL})$ and EtOAc $(15 \mathrm{~mL})$. The aqueous layer was extracted with EtOAc $(3 \times 20 \mathrm{~mL})$ and the combined organic layers were washed with $\mathrm{H}_{2} \mathrm{O}(4 \times 15 \mathrm{~mL})$, brine (25 mL), dried $\left(\mathrm{MgSO}_{4}\right)$ and concentrated in vacuo to afford a clear liquid. Purification by flash chromatography (50:50 EtOAc/hexanes-70:30 EtOAc/hexanes) furnished the title compound 30 as a white solid $(0.460 \mathrm{~g}, 80 \%): \mathrm{mp}=113-115^{\circ} \mathrm{C} ;{ }^{1} \mathrm{H} \mathrm{NMR}\left(500 \mathrm{MHz}, \mathrm{CDCl}_{3}\right) \delta 4.20(\mathrm{~m}, 1 \mathrm{H})$, $3.88(\mathrm{dd}, J=11.1,4.6,1 \mathrm{H}), 3.79(\mathrm{dd}, J=11.1,6.6,1 \mathrm{H}), 3.01-2.94(\mathrm{~m}, 1 \mathrm{H}), 2.80($ br s, $1 \mathrm{H})$, 2.59-2.52 (m, 2H), $2.44(\mathrm{dd}, J=14.8,2.4,1 \mathrm{H}), 2.24(\mathrm{dd}, J=14.8,8.4,1 \mathrm{H}), 2.18-2.11(\mathrm{~m}, 1 \mathrm{H})$, $1.52(\mathrm{~s}, 9 \mathrm{H}) ;{ }^{13} \mathrm{C} \mathrm{NMR}\left(125 \mathrm{MHz}, \mathrm{CDCl}_{3}\right) \delta 176.1,171.1,150.5,85.7,85.0,64.0,56.9,33.6$, 30.8, 28.8, 28.3; IR (KBr) 3494, 2989, 2935, 1789, 1765, 1371, 1289, $1150 \mathrm{~cm}^{-1}$; HRMS 
$(\mathrm{CI} / \mathrm{methanol}) \mathrm{m} / \mathrm{z}$ calcd for $\mathrm{C}_{13} \mathrm{H}_{19} \mathrm{NO}_{6}(\mathrm{M}+\mathrm{Na})^{+} 308.1110$, found 308.1112; $[\alpha]^{24}{ }_{\mathrm{D}}-69.5^{\circ}(c$ $\left.0.21, \mathrm{CHCl}_{3}\right)$.

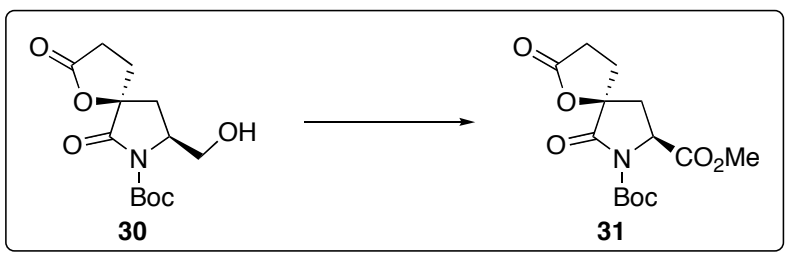

Methyl ester (31): To a solution of alcohol $30(0.212 \mathrm{~g}, 0.744 \mathrm{mmol})$ in $\mathrm{CH}_{3} \mathrm{CN} / \mathrm{CCl}_{4} / \mathrm{H}_{2} \mathrm{O}(2$ $\mathrm{mL} / 2 \mathrm{~mL} / 3 \mathrm{~mL})$ was added $\mathrm{NaIO}_{4}(0.651 \mathrm{~g}, 3.05 \mathrm{mmol})$. The reaction mixture was stirred vigorously for $5 \mathrm{~min}$ before $\mathrm{RuCl}_{3}(0.005 \mathrm{~g}, 0.022 \mathrm{mmol})$ was added. The resulting brown solution was stirred for $3 \mathrm{~h}$ at $\mathrm{RT}$ and turned a bright orange color. The reaction was quenched by the addition of isopropanol $(1 \mathrm{~mL})$ and the resulting black reaction mixture was diluted with $\mathrm{Et}_{2} \mathrm{O}(4 \mathrm{~mL})$ and stirred for $30 \mathrm{~min}$. The mixture was filtered through celite, the celite pad was washed with $\mathrm{Et}_{2} \mathrm{O}(2 \times 4 \mathrm{~mL})$ and $\mathrm{CH}_{2} \mathrm{Cl}_{2}(3 \times 5 \mathrm{~mL})$, and the filtrate was dried over $\mathrm{MgSO}_{4}$ and concentrated in vacuo to yield a crude solid. The crude solid was dissolved in EtOAc/MeOH (4

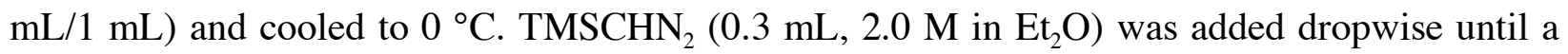
bright yellow color persisted. After stirring for $20 \mathrm{~min}$ at $0{ }^{\circ} \mathrm{C}, \mathrm{AcOH}$ was added dropwise until the solution turned colorless. The solution was neutralized by the addition of saturated aqueous $\mathrm{NaHCO}_{3}(2 \mathrm{~mL})$ and diluted with $\mathrm{H}_{2} \mathrm{O}(4 \mathrm{~mL})$. The aqueous layer was extracted with EtOAc $(3 \mathrm{x}$ $8 \mathrm{~mL})$ and the combined organic layers were washed with brine $(12 \mathrm{~mL})$, dried $\left(\mathrm{MgSO}_{4}\right)$, and concentrated in vacuo. The resulting crude oil was purified by flash chromatography (50:50 EtOAc/hexanes) to afford the title compound as a white solid $(0.177 \mathrm{~g}, 76 \%): \mathrm{mp}=140-143{ }^{\circ} \mathrm{C}$; ${ }^{1} \mathrm{H}$ NMR $\left(500 \mathrm{MHz}, \mathrm{CDCl}_{3}\right) \delta 4.64(\mathrm{dd}, J=8.8,3.5,1 \mathrm{H}), 3.81(\mathrm{~s}, 3 \mathrm{H}), 3.00(\mathrm{dt}, J=17.5,10.9$, 
$1 \mathrm{H}), 2.62-2.56(\mathrm{~m}, 2 \mathrm{H}), 2.54(\mathrm{~d}, J=3.6,1 \mathrm{H}), 2.48(\mathrm{dd}, J=14.5,9.0,1 \mathrm{H}), 2.14(\mathrm{dt}, J=13.6$, 10.2, 1H), $1.52(\mathrm{~s}, 9 \mathrm{H}) ;{ }^{13} \mathrm{C} \mathrm{NMR}\left(125 \mathrm{MHz}, \mathrm{CDCl}_{3}\right) \delta$ 175.4, 170.5, 170.3, 149.3, 65.2, 84.7, 56.0, 53.4, 34.5, 30.5, 28.7, 28.2; IR (KBr) 2982, 1796, 1748, 1289, $1157 \mathrm{~cm}^{-1}$; HRMS $(\mathrm{CI} /$ methanol $) m / z$ calcd for $\mathrm{C}_{14} \mathrm{H}_{19} \mathrm{NO}_{7}(\mathrm{M}+\mathrm{Na})^{+} 336.1059$, found $336.1052 ;[\alpha]^{24}-74.2^{\circ}(c$ $\left.0.15, \mathrm{CHCl}_{3}\right)$. 
II. ${ }^{1} \mathrm{H}$ NMR and ${ }^{13} \mathrm{C}$ NMR Spectra for Compounds $3,14,15,17,18,20-22,24$, 26, 29, 30, 31 


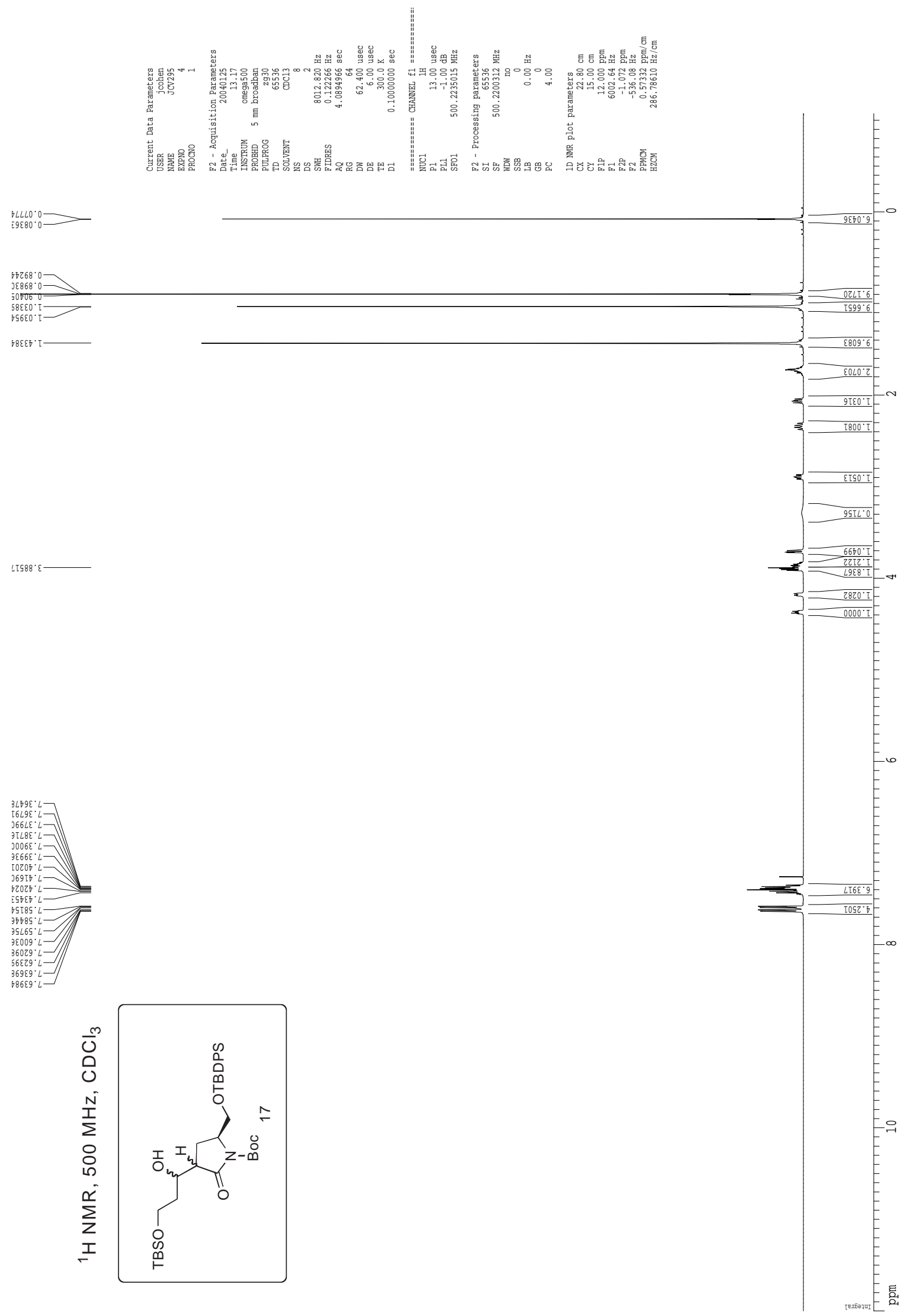




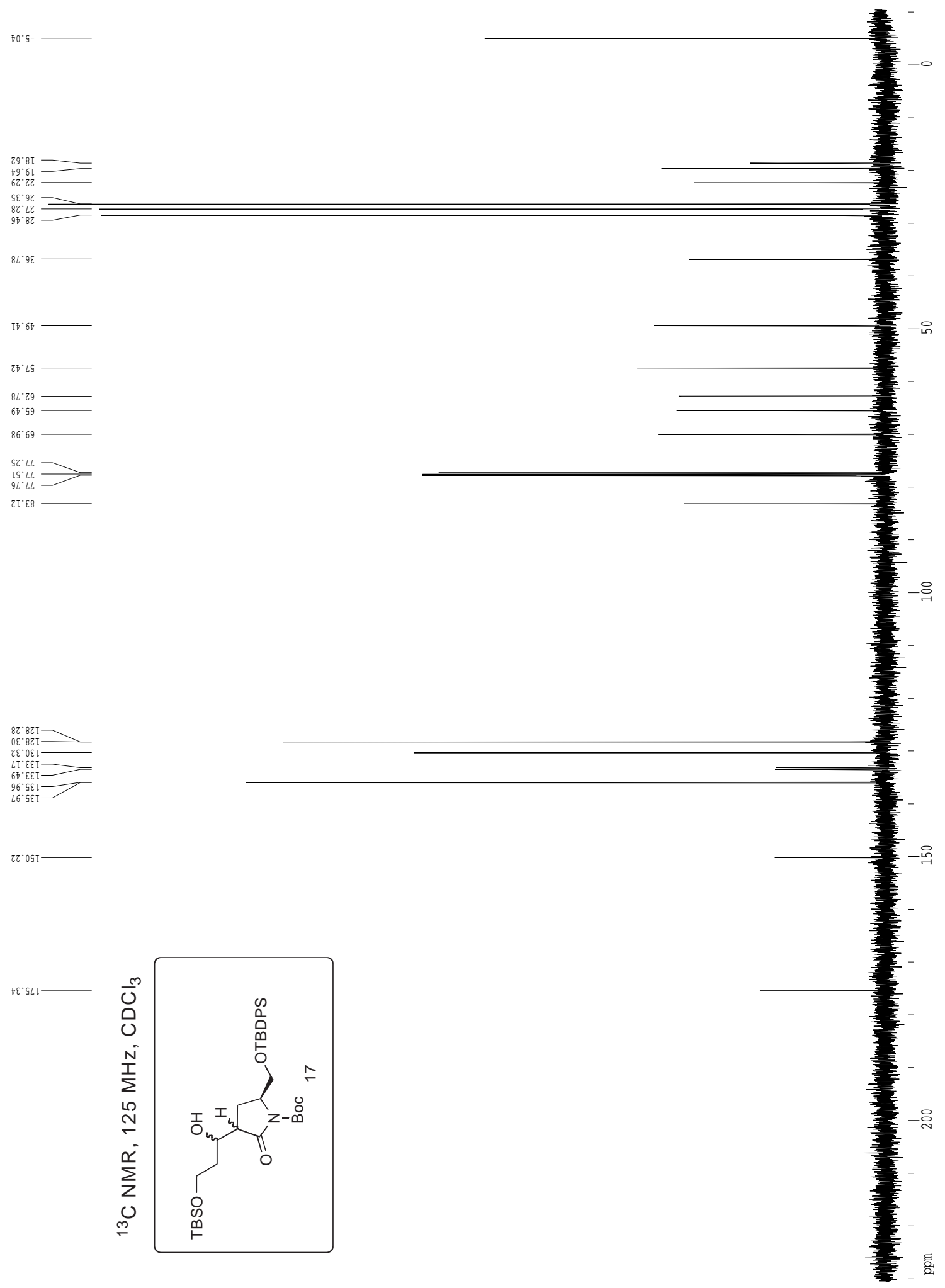




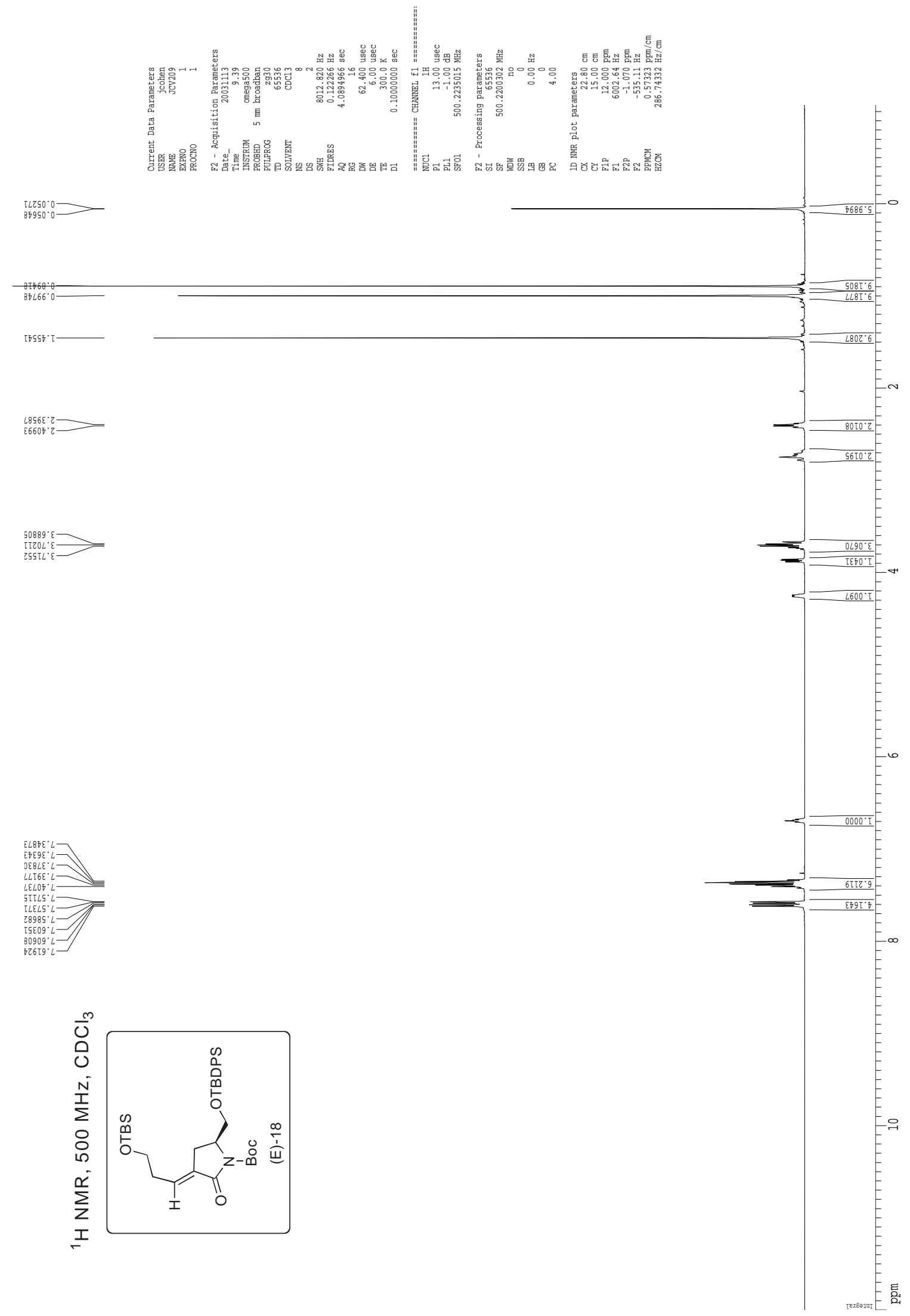




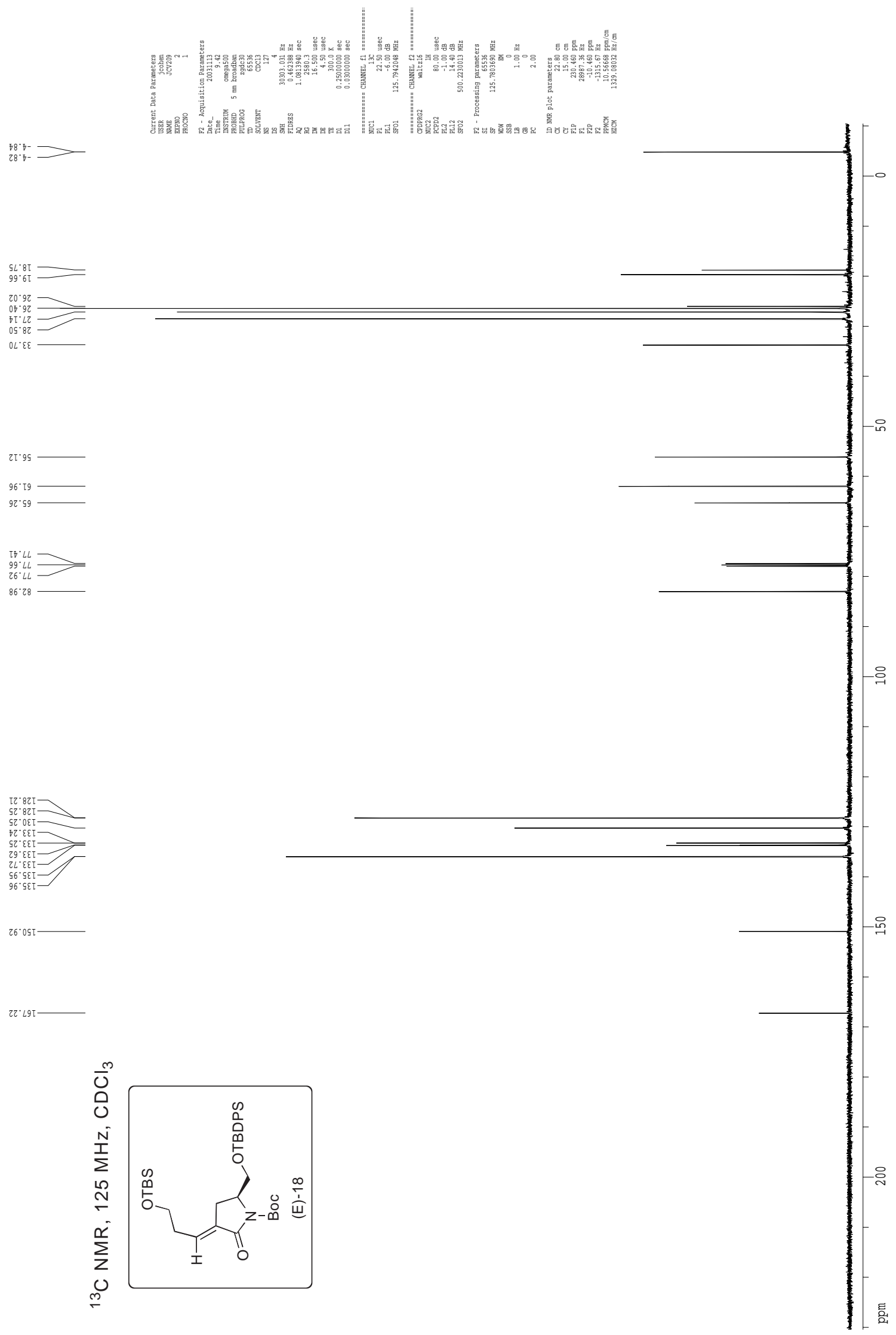




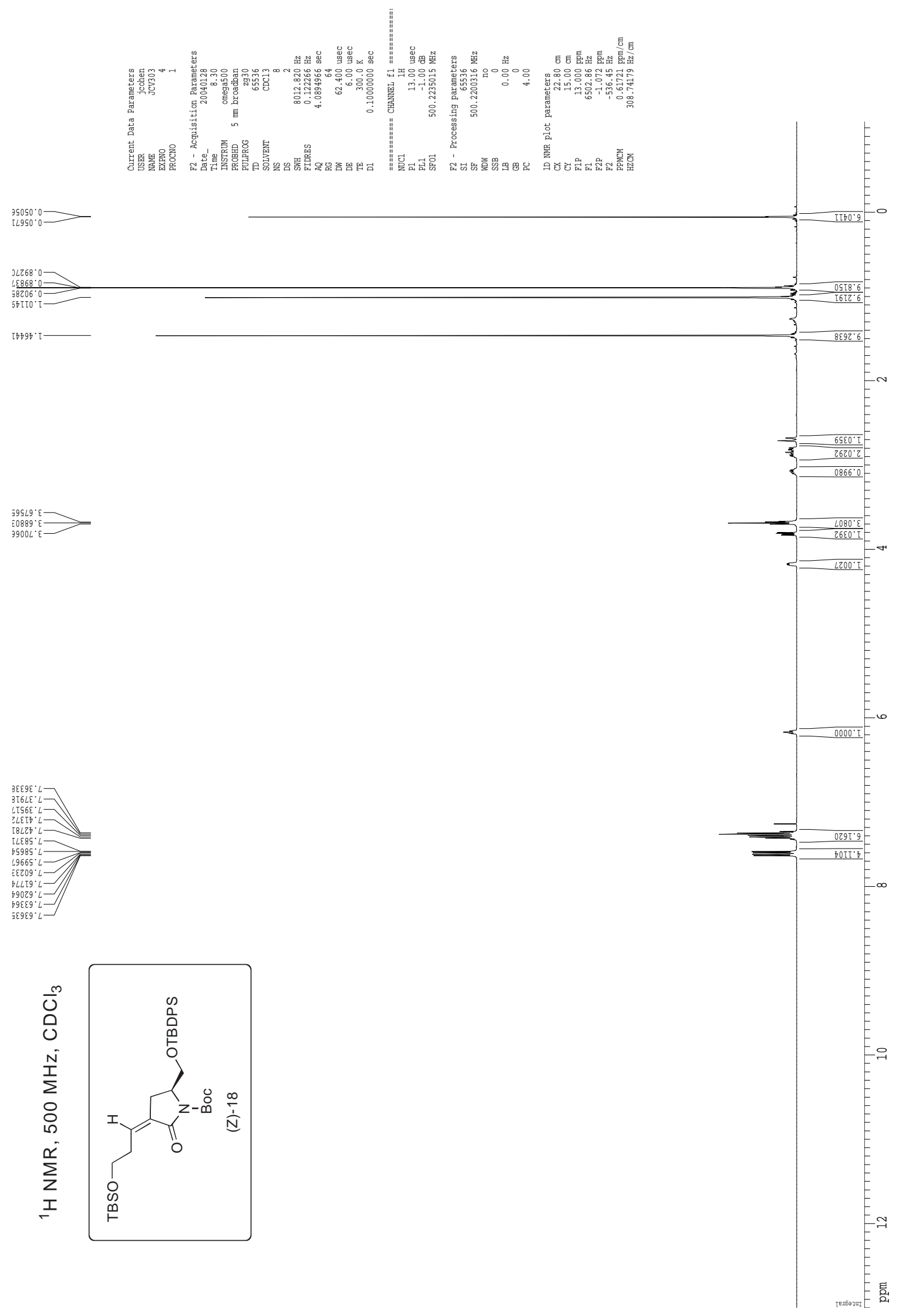




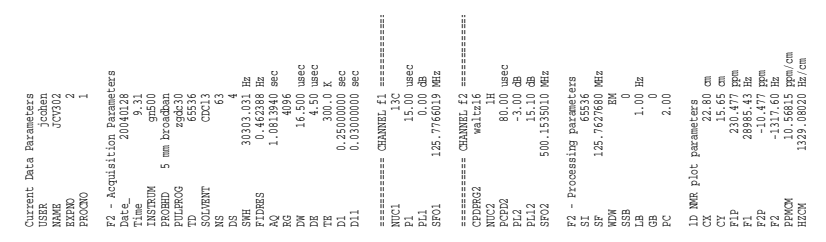

$28^{\circ} 6-$
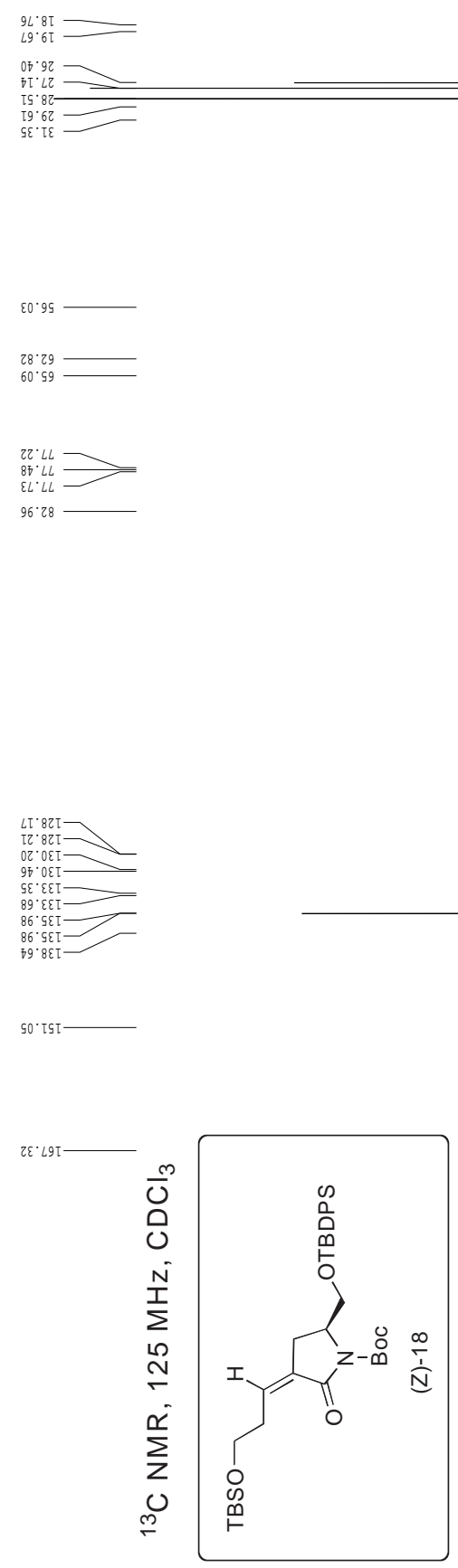


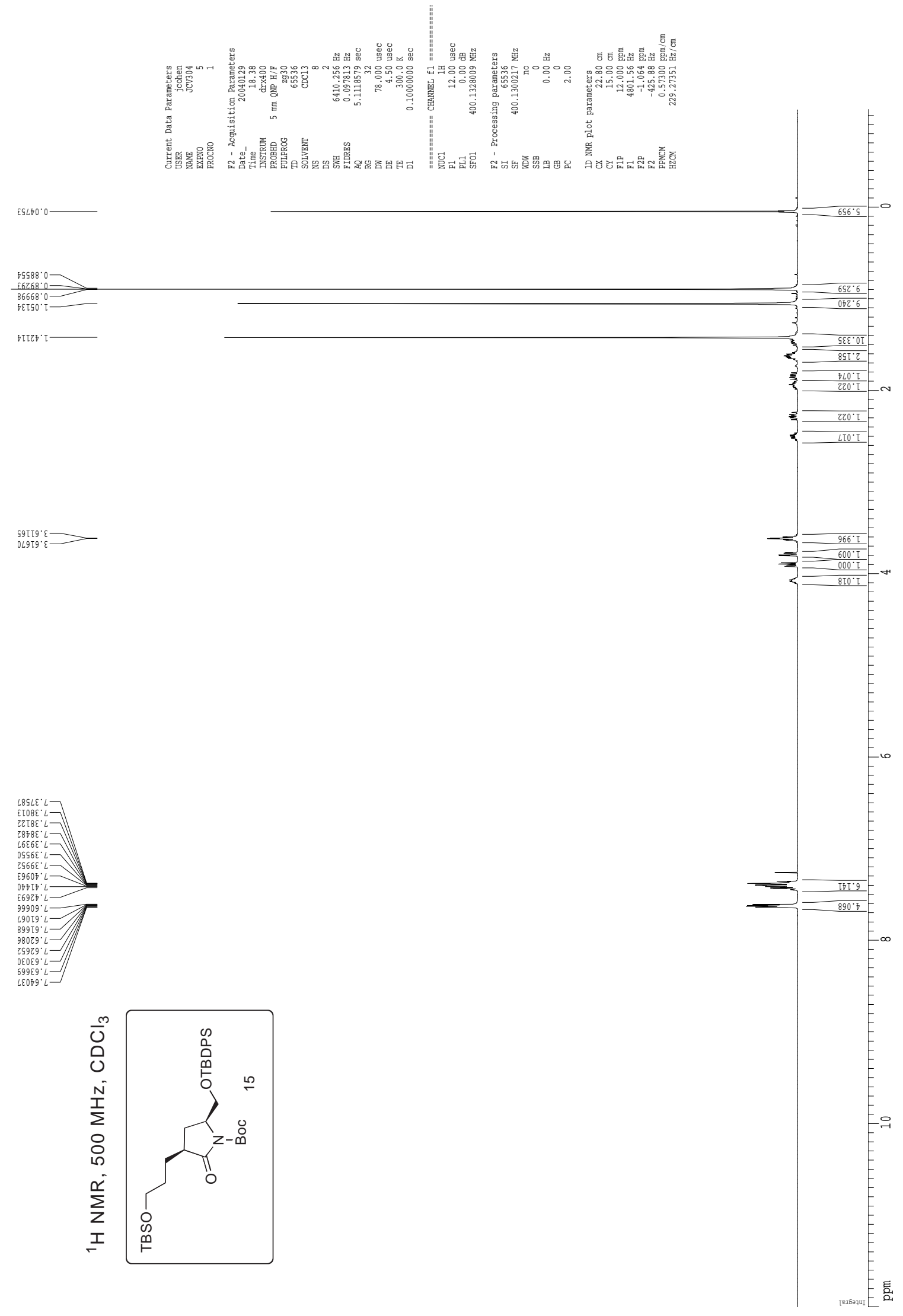




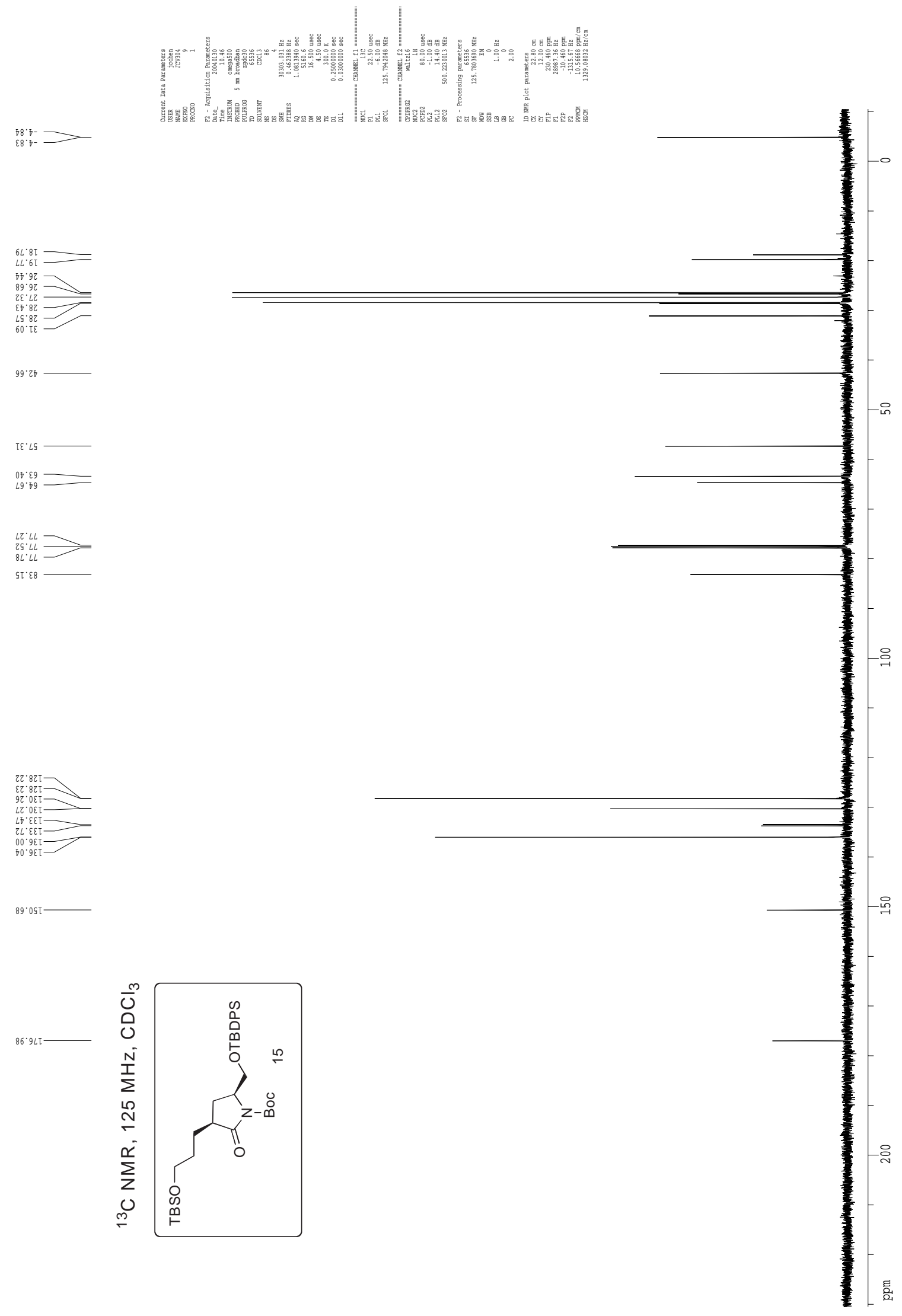




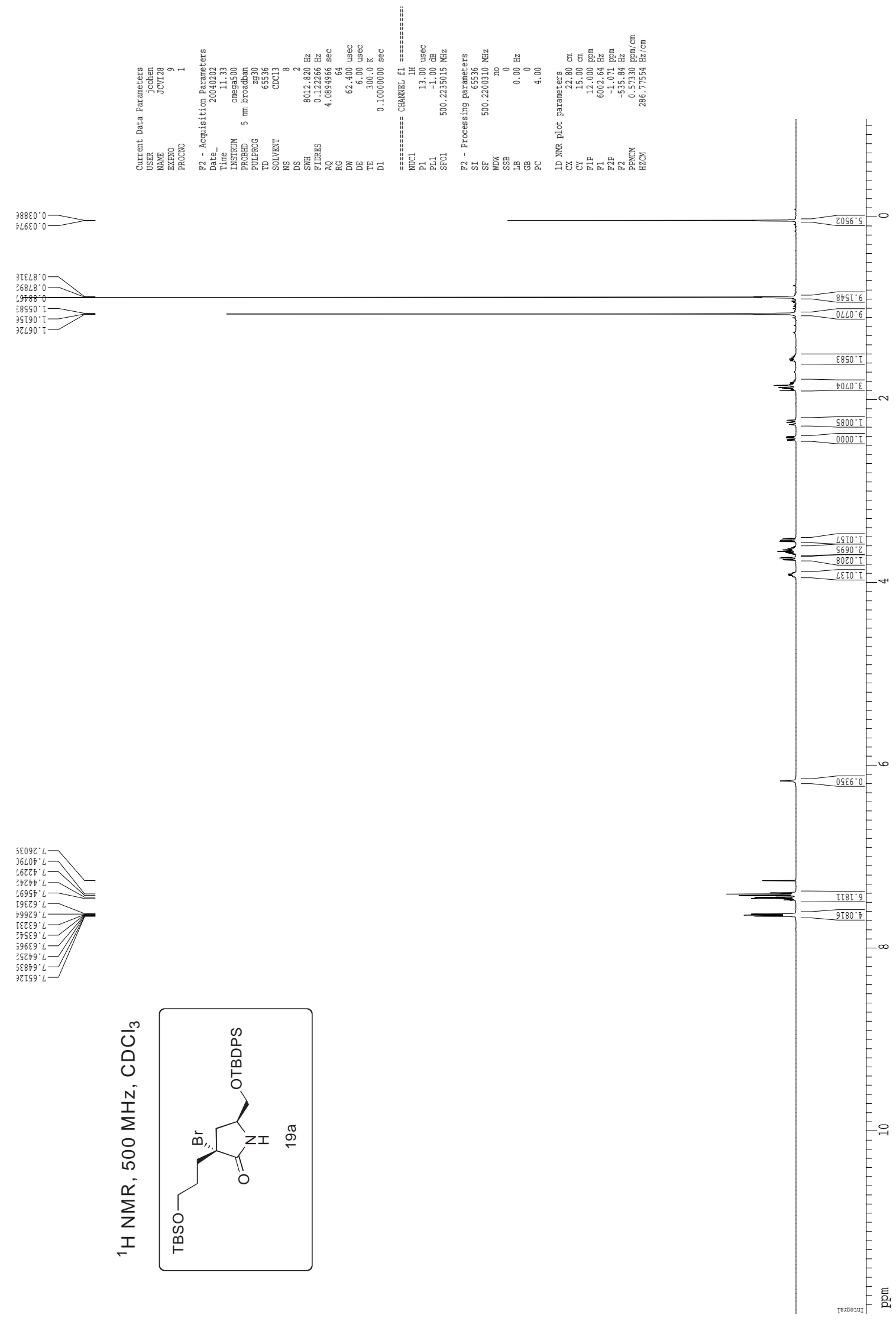



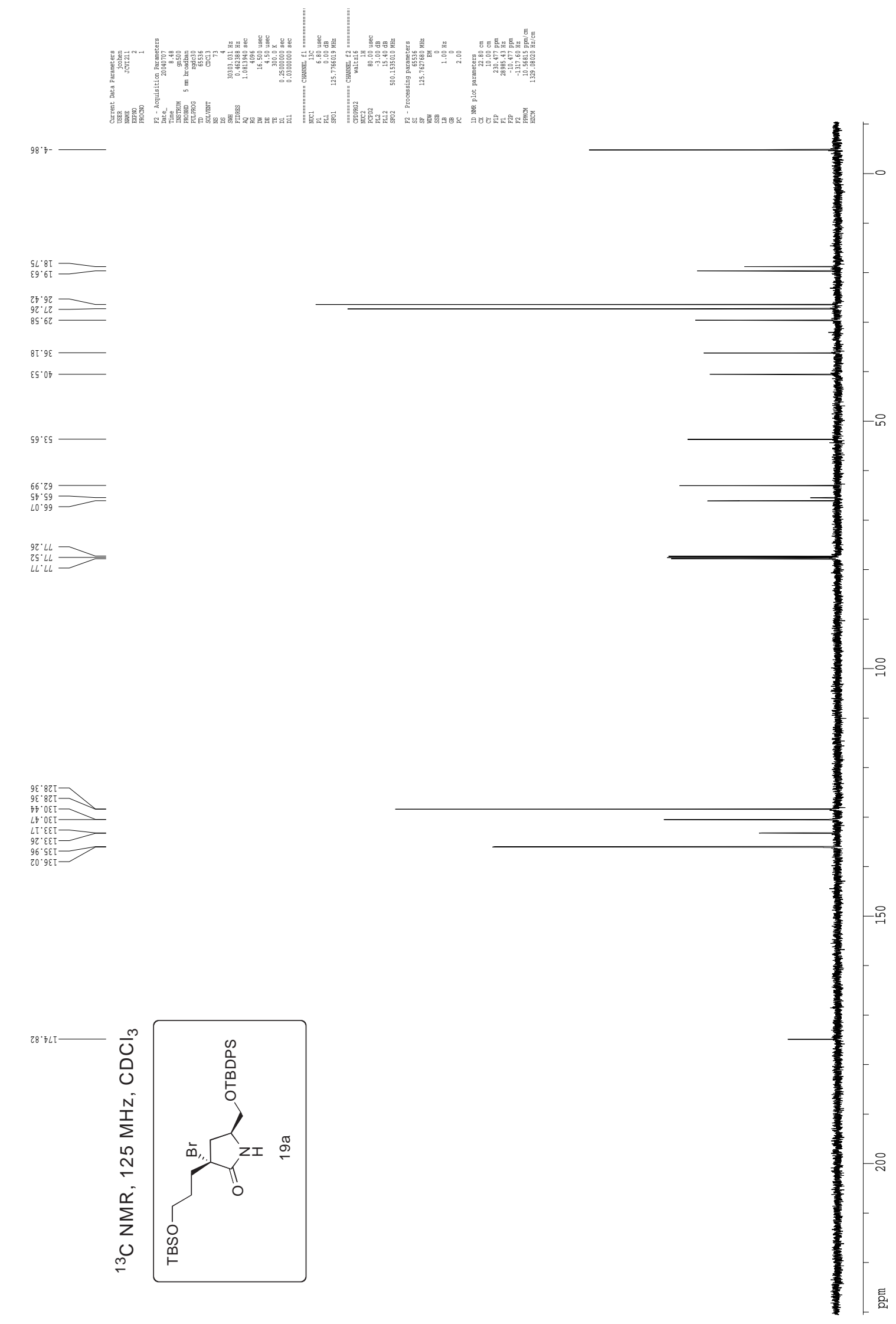

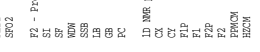




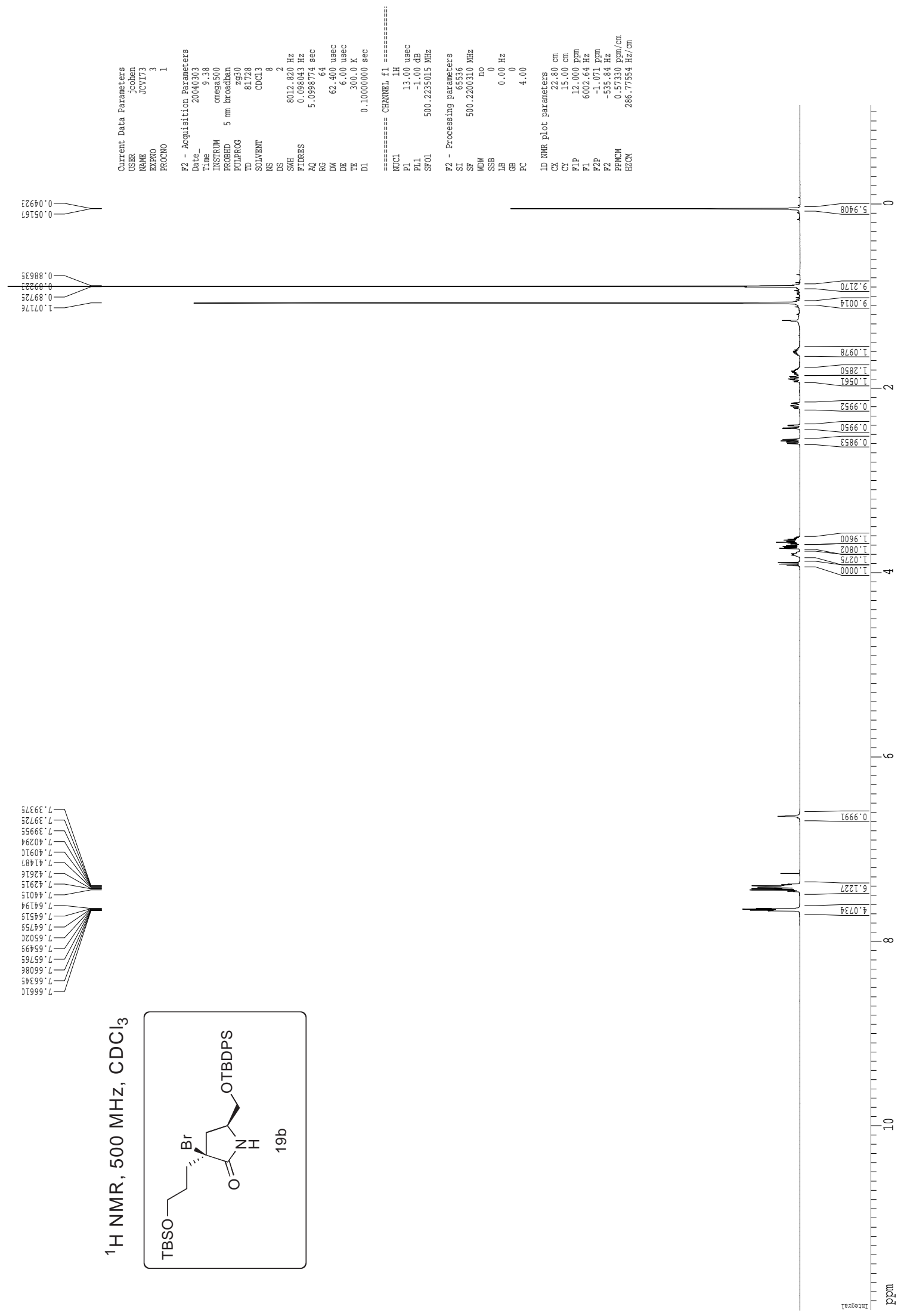




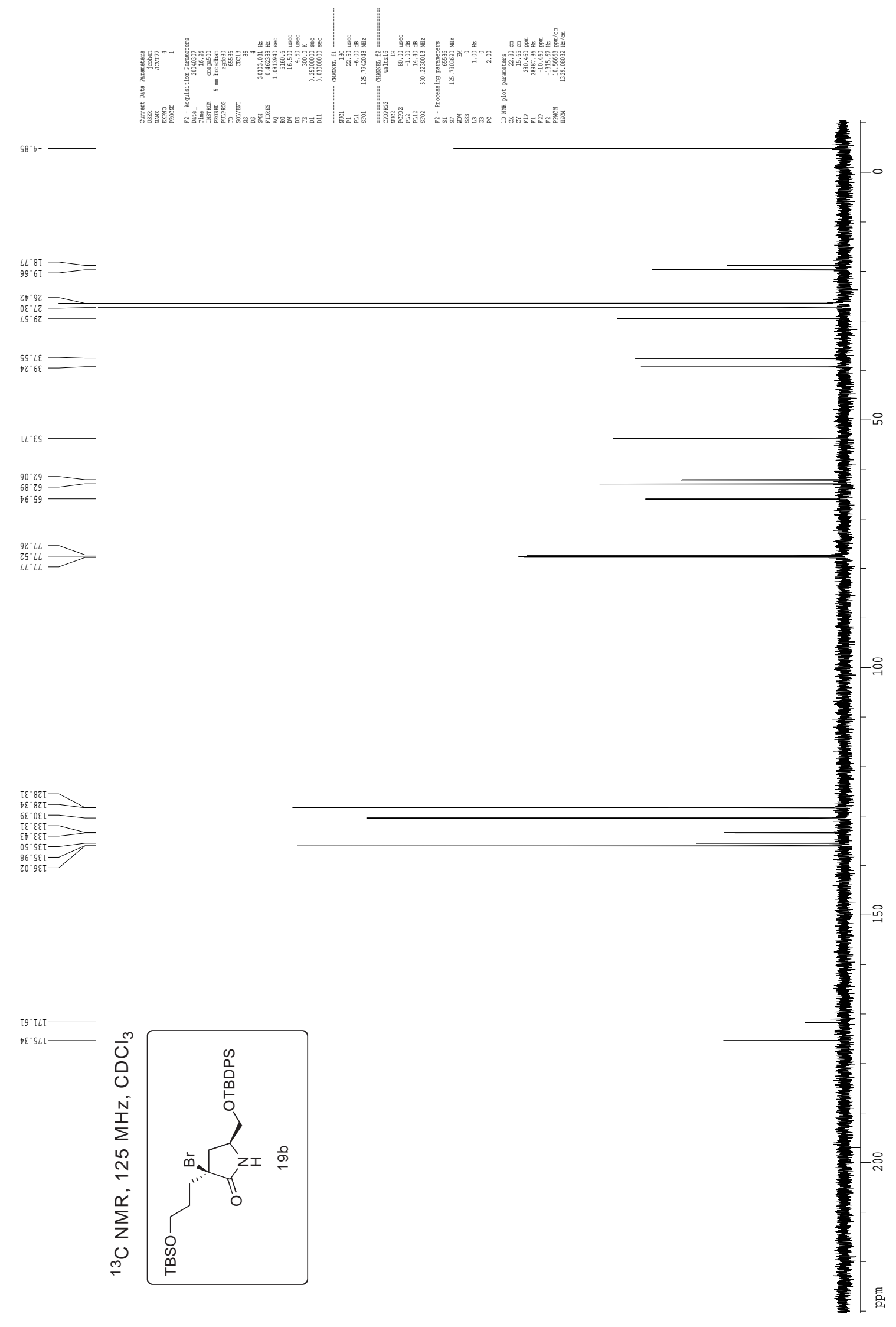




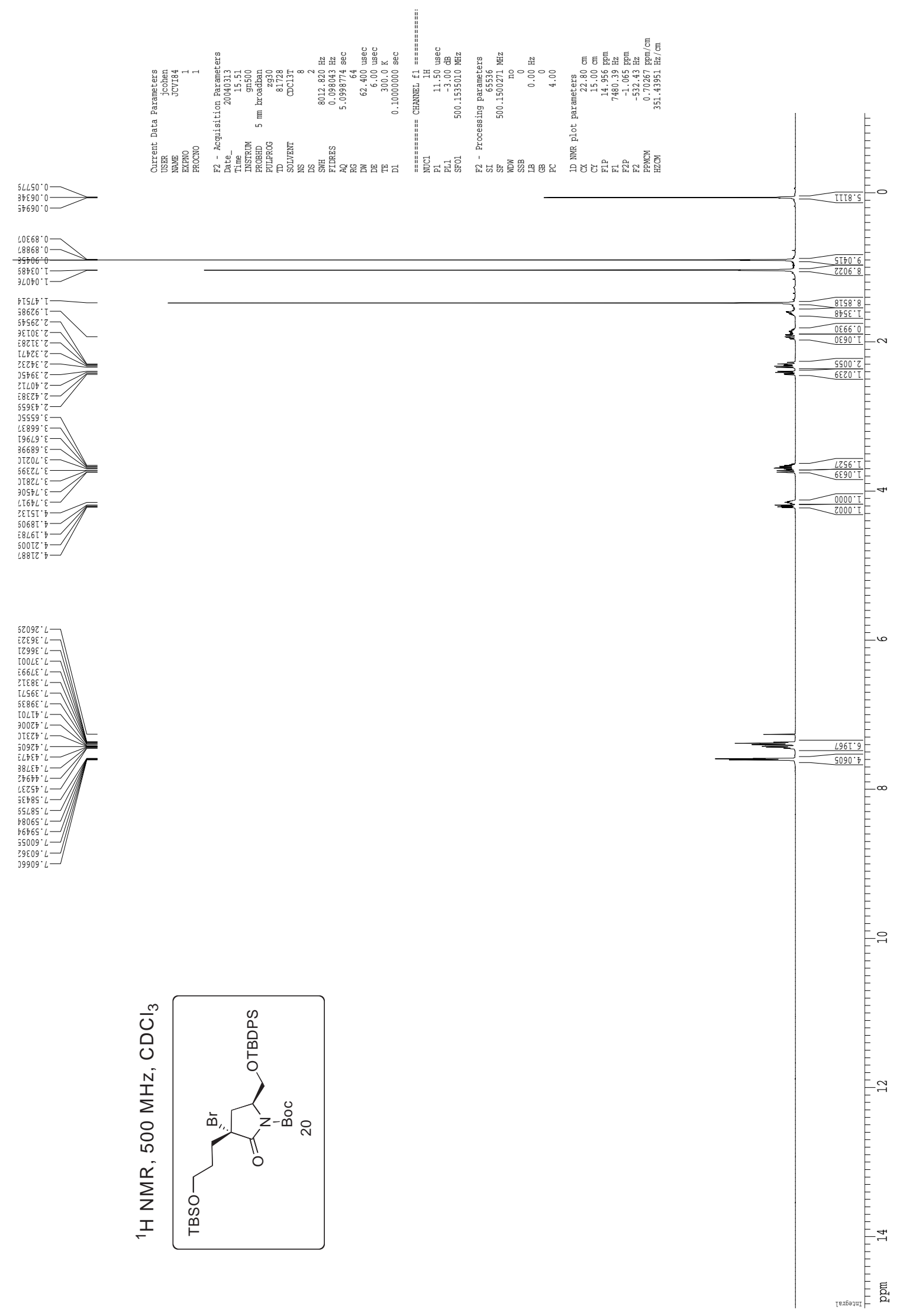




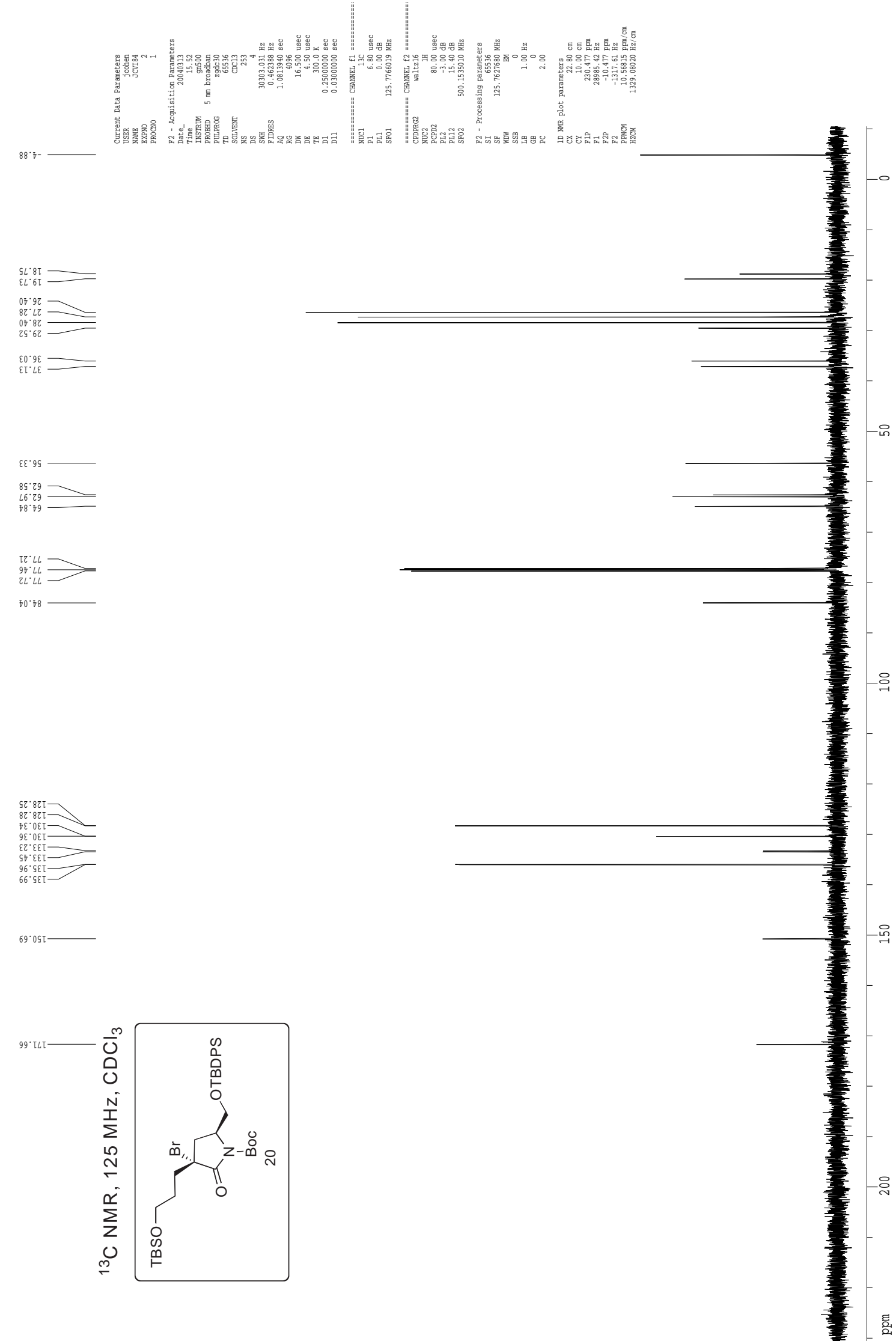



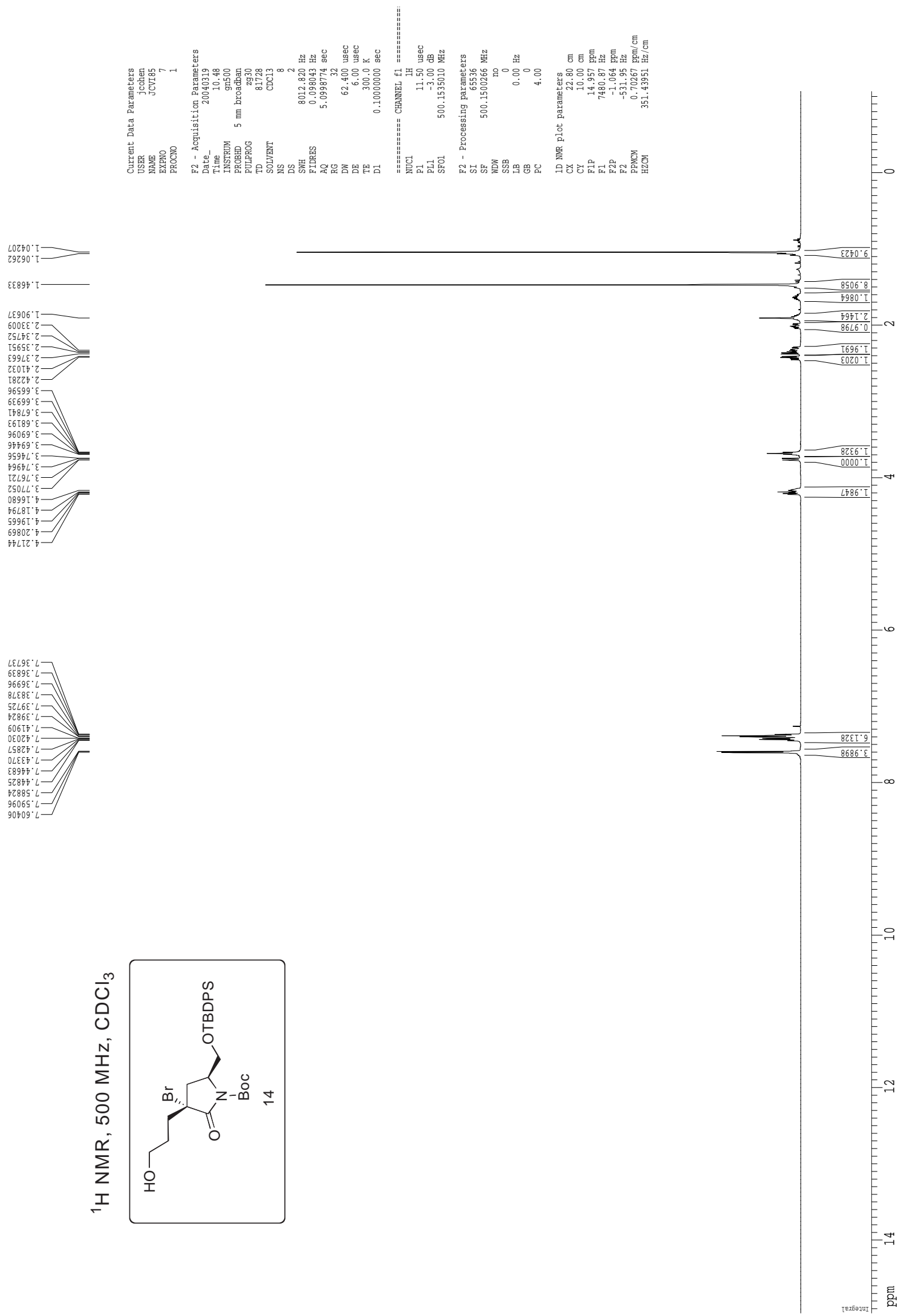

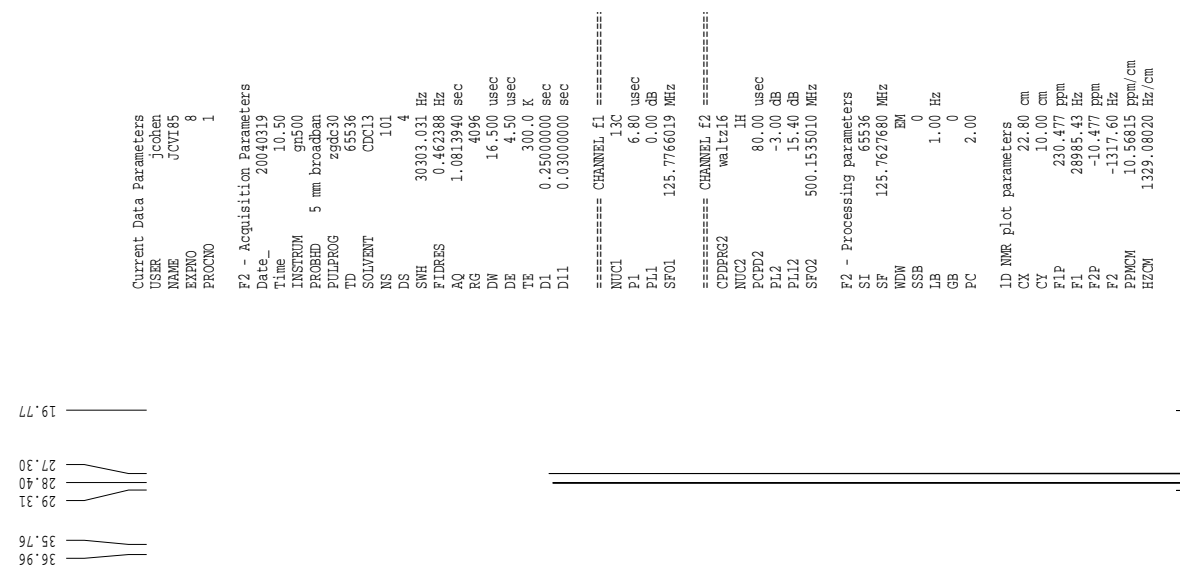

$9 \varepsilon \cdot 99$
$90^{\circ} \cdot 29$
$\tau \cdot 29$
$00^{\circ} \cdot 69$

$62 \cdot L L$
$59 \cdot L L$

$L T^{\circ} \cdot 88$

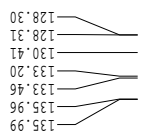

85. OSI -
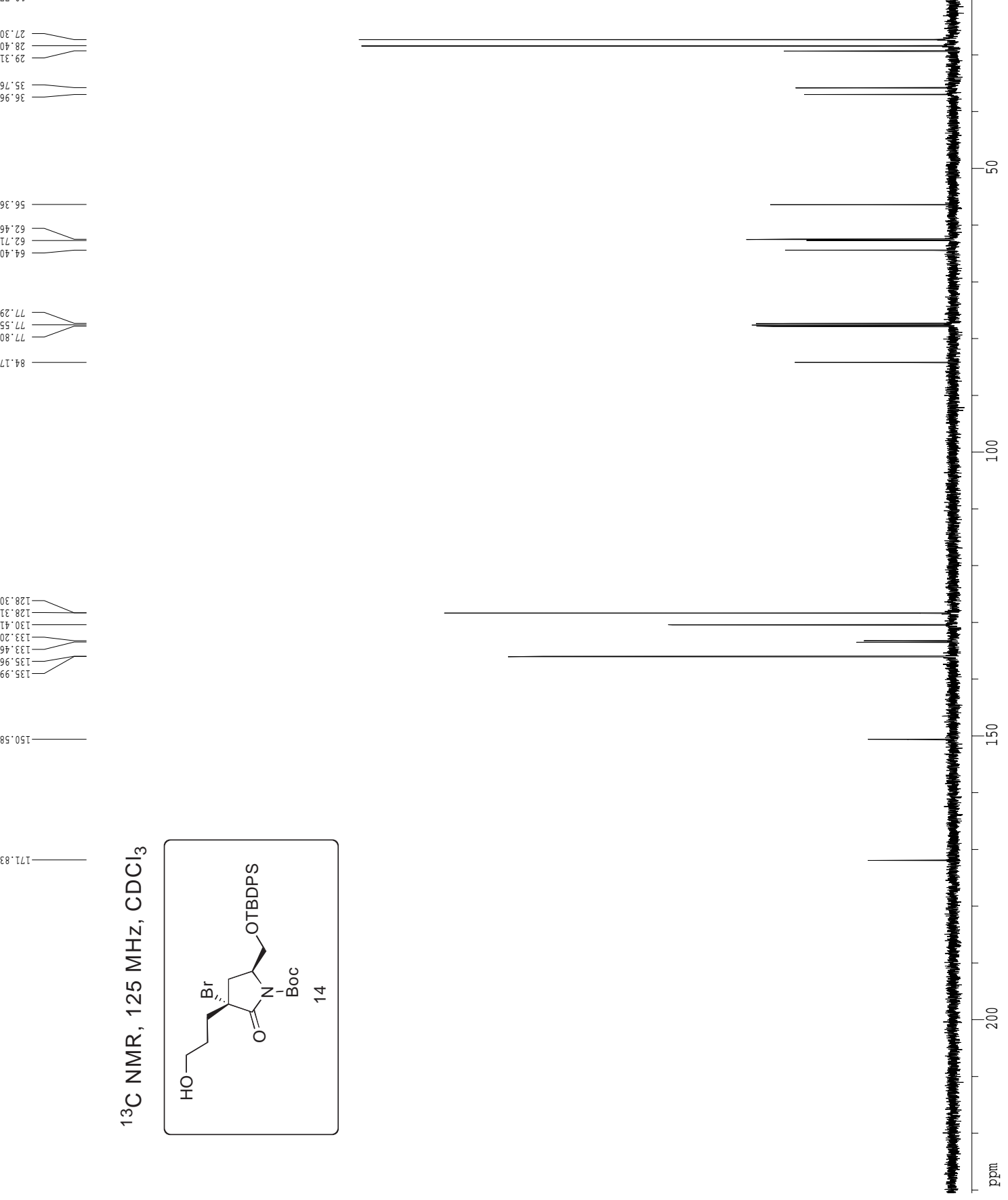

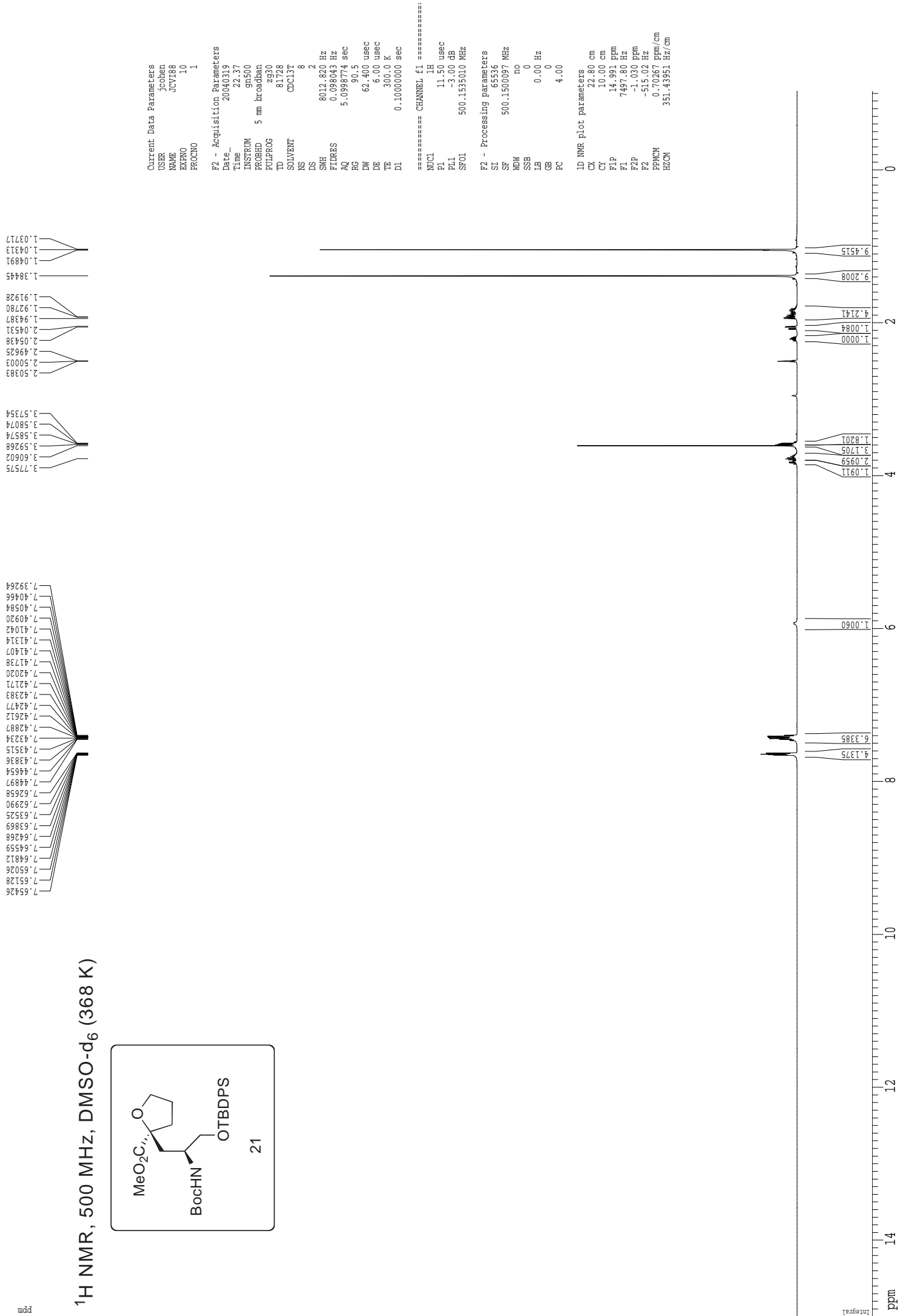

wdd

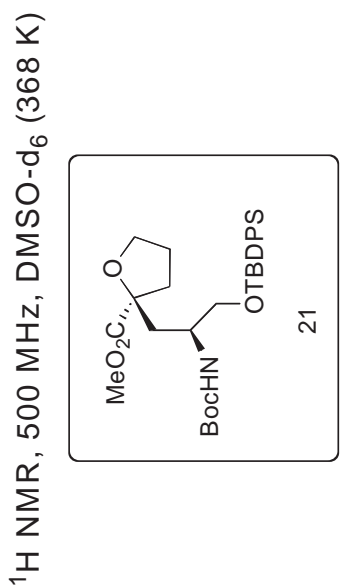



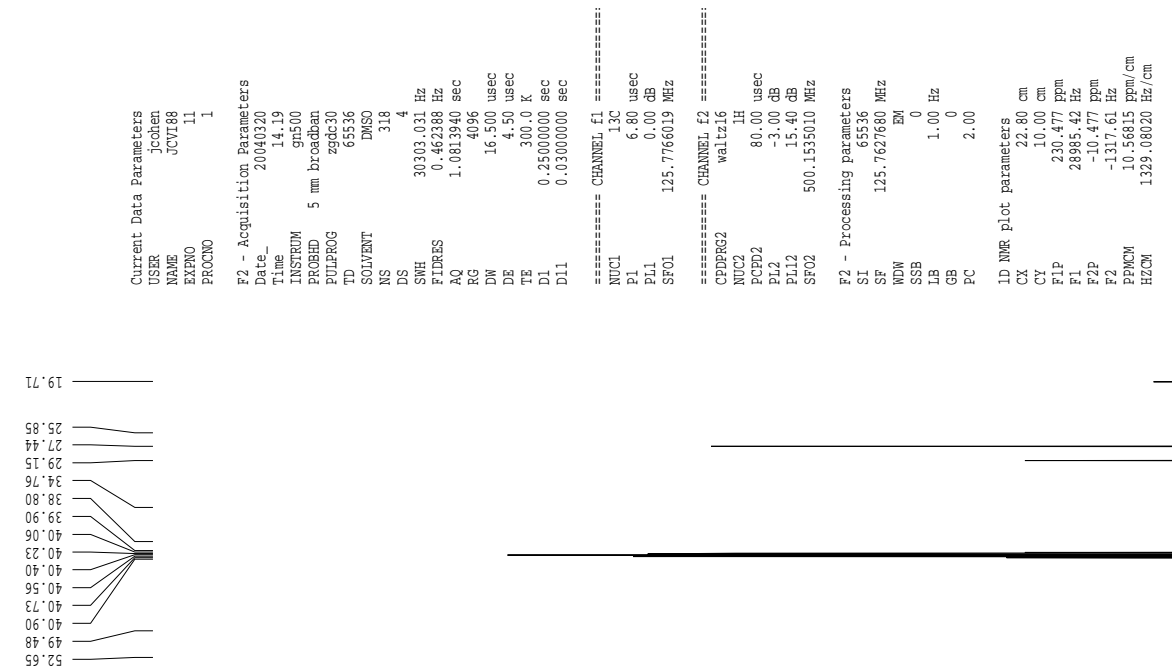

${ }_{80}^{86.99}=$

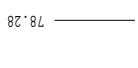

$\varepsilon \triangleright,\ulcorner 8$

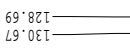

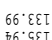

$66^{\circ} \mathrm{SE}-$
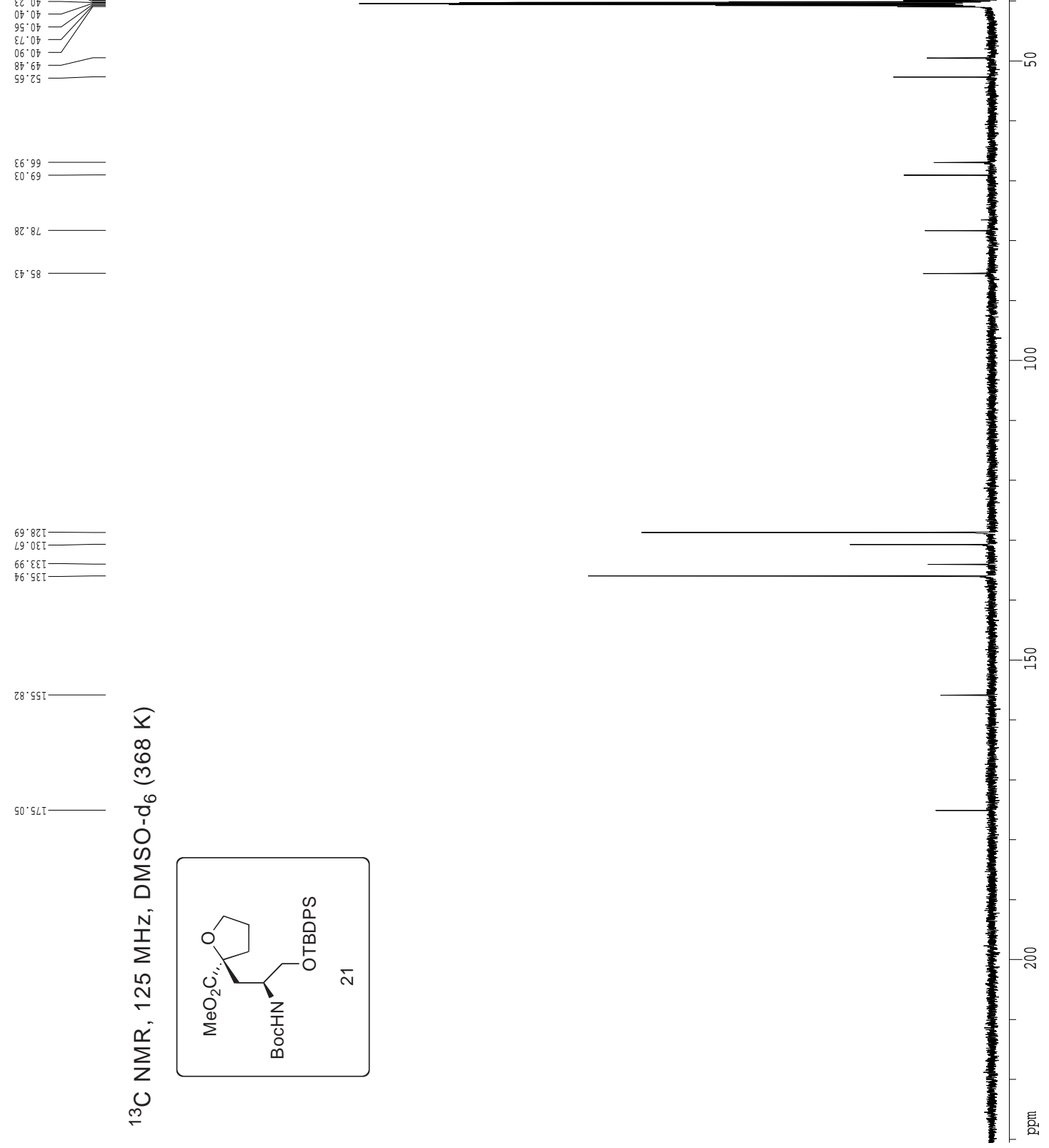


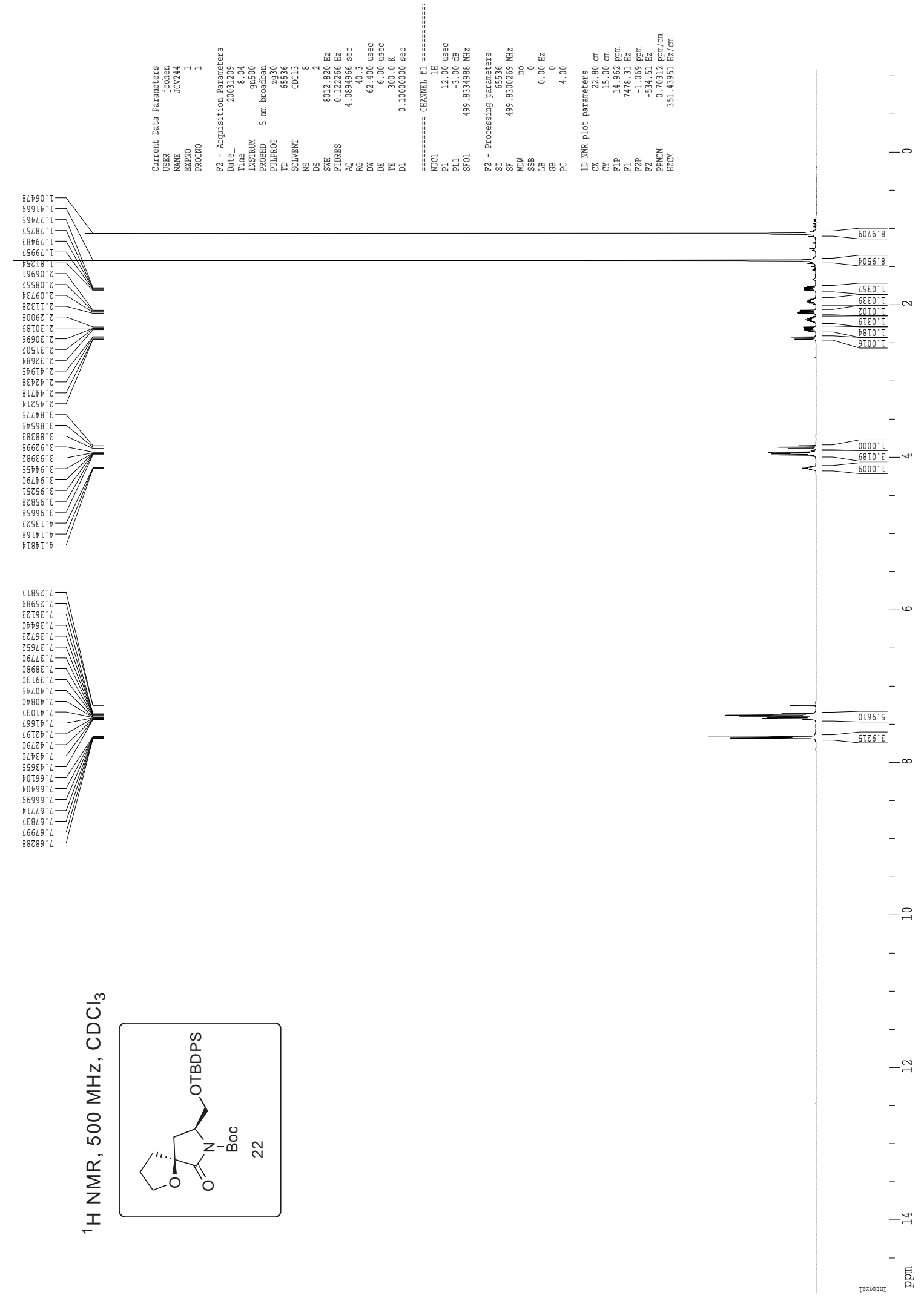



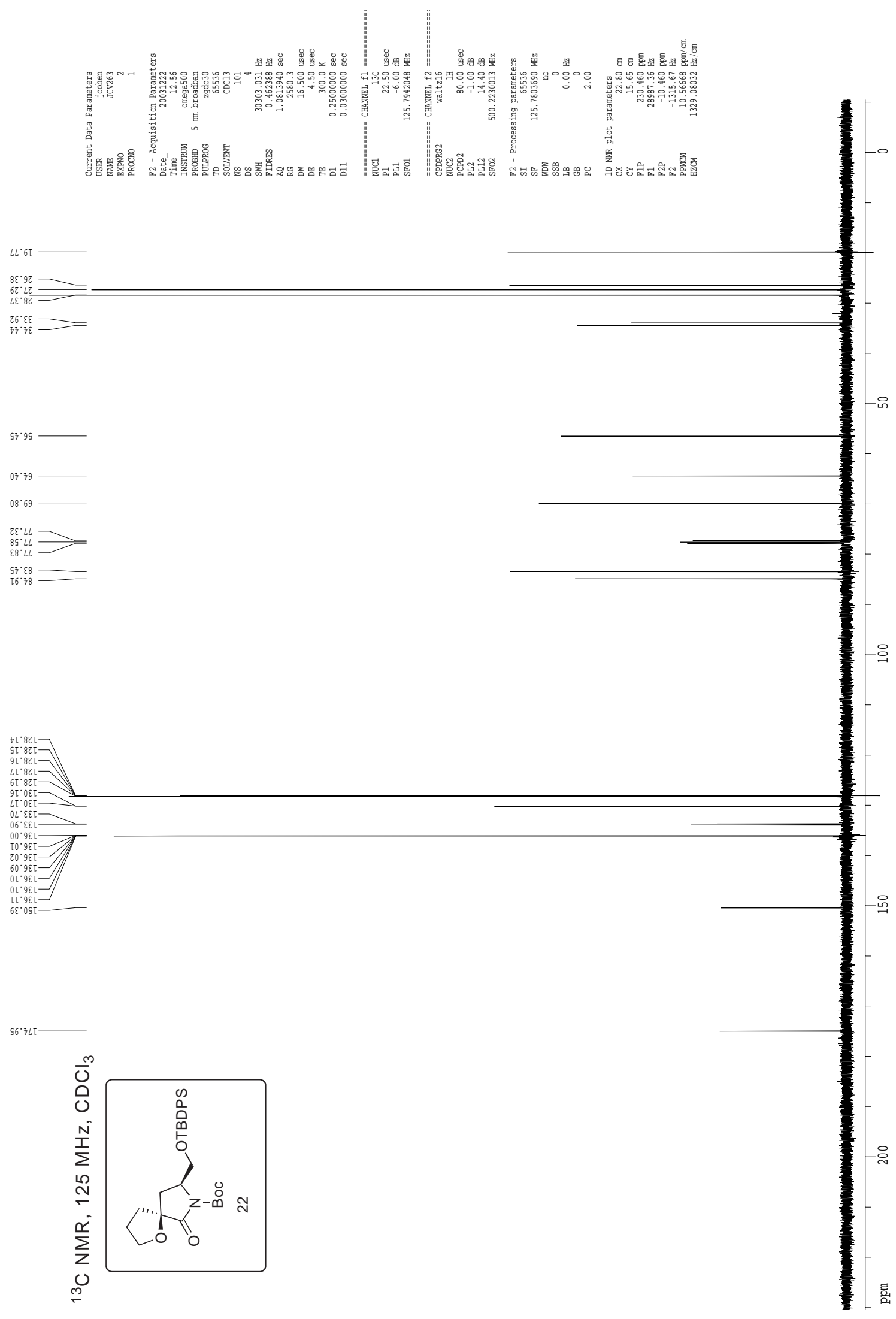

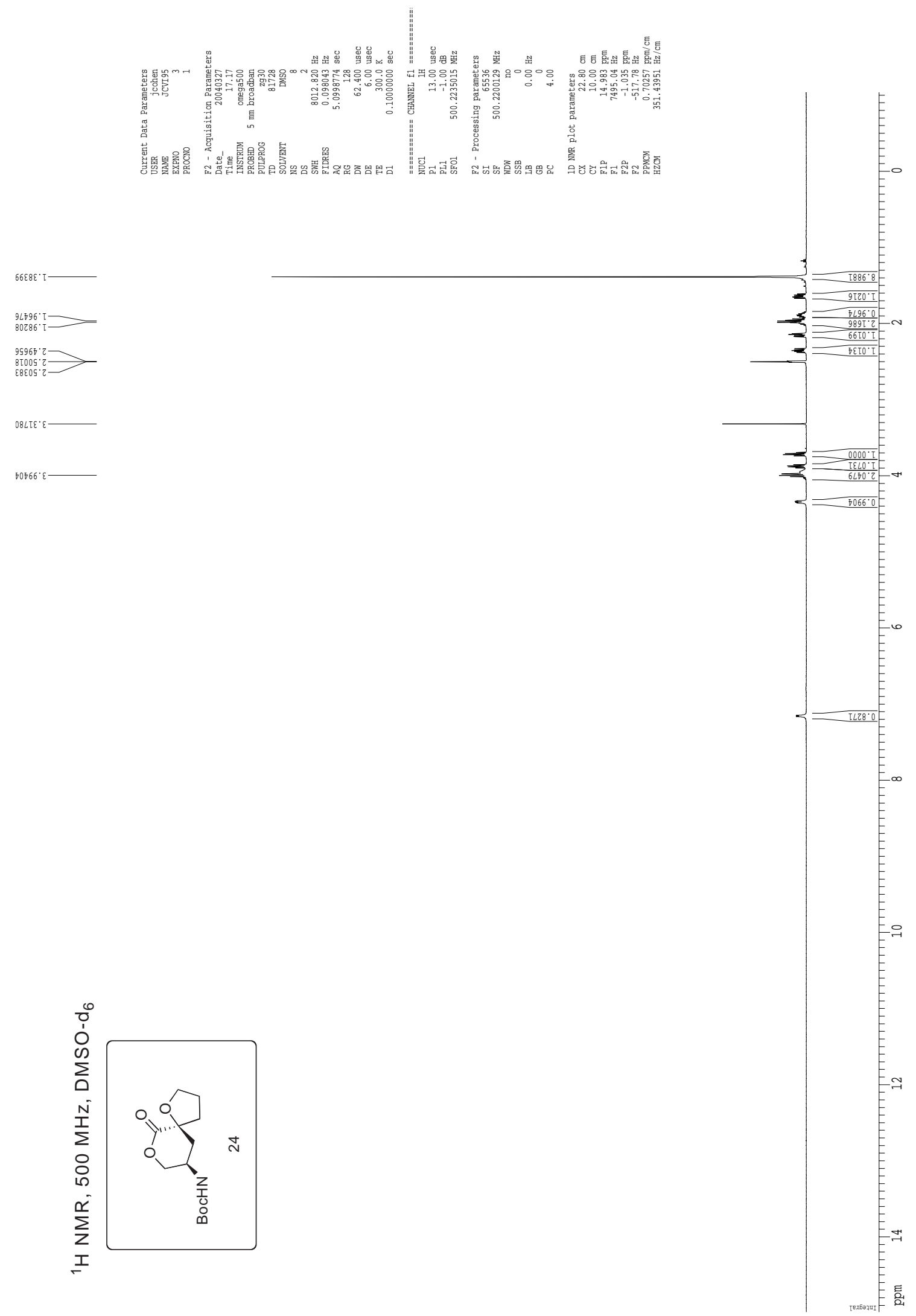

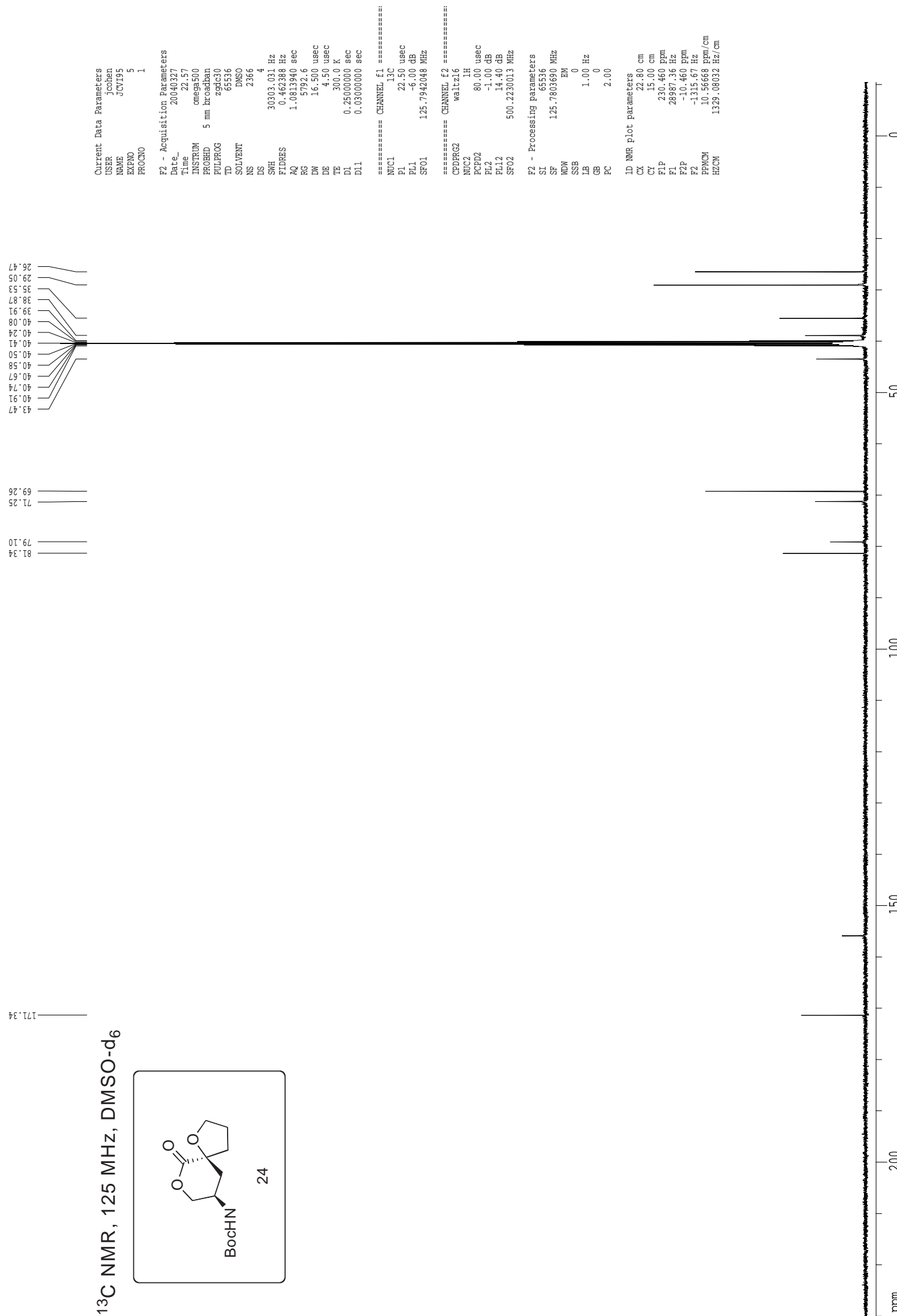

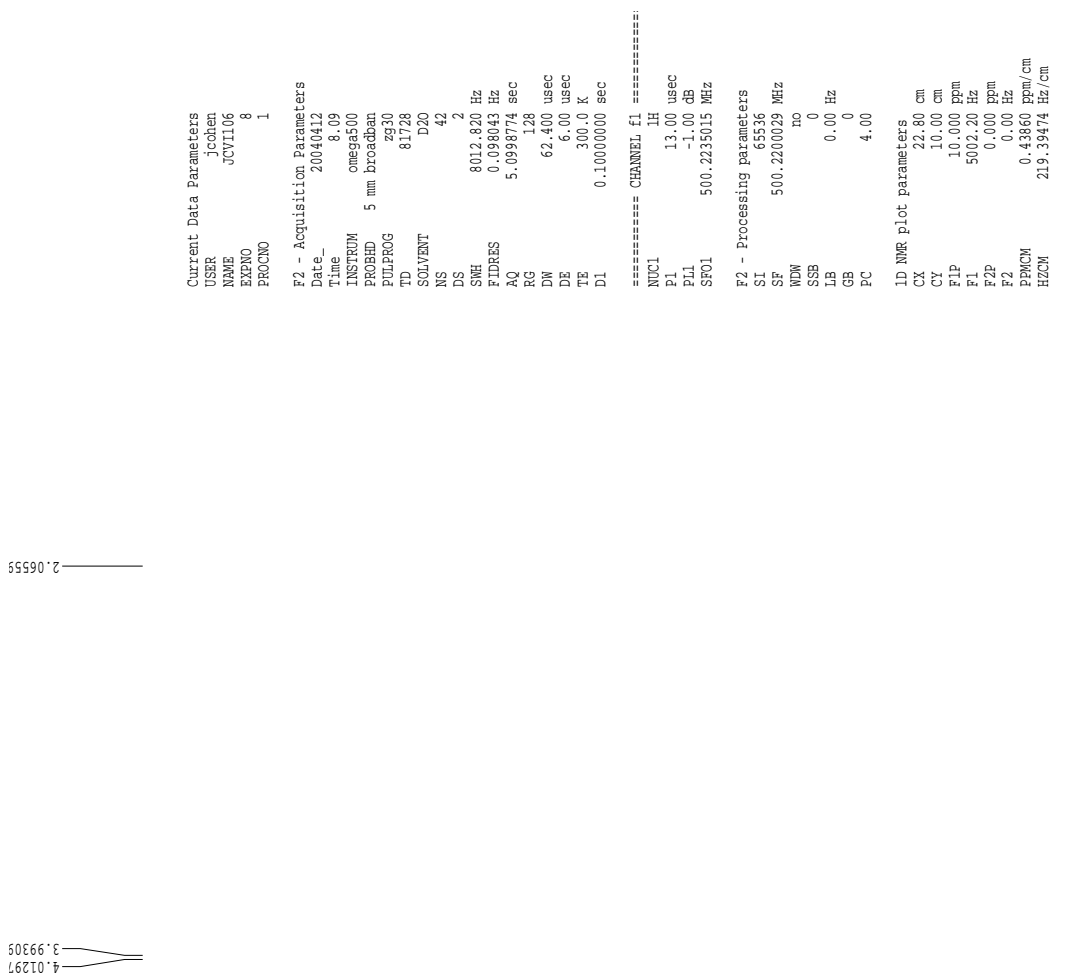

$32008^{\circ}$
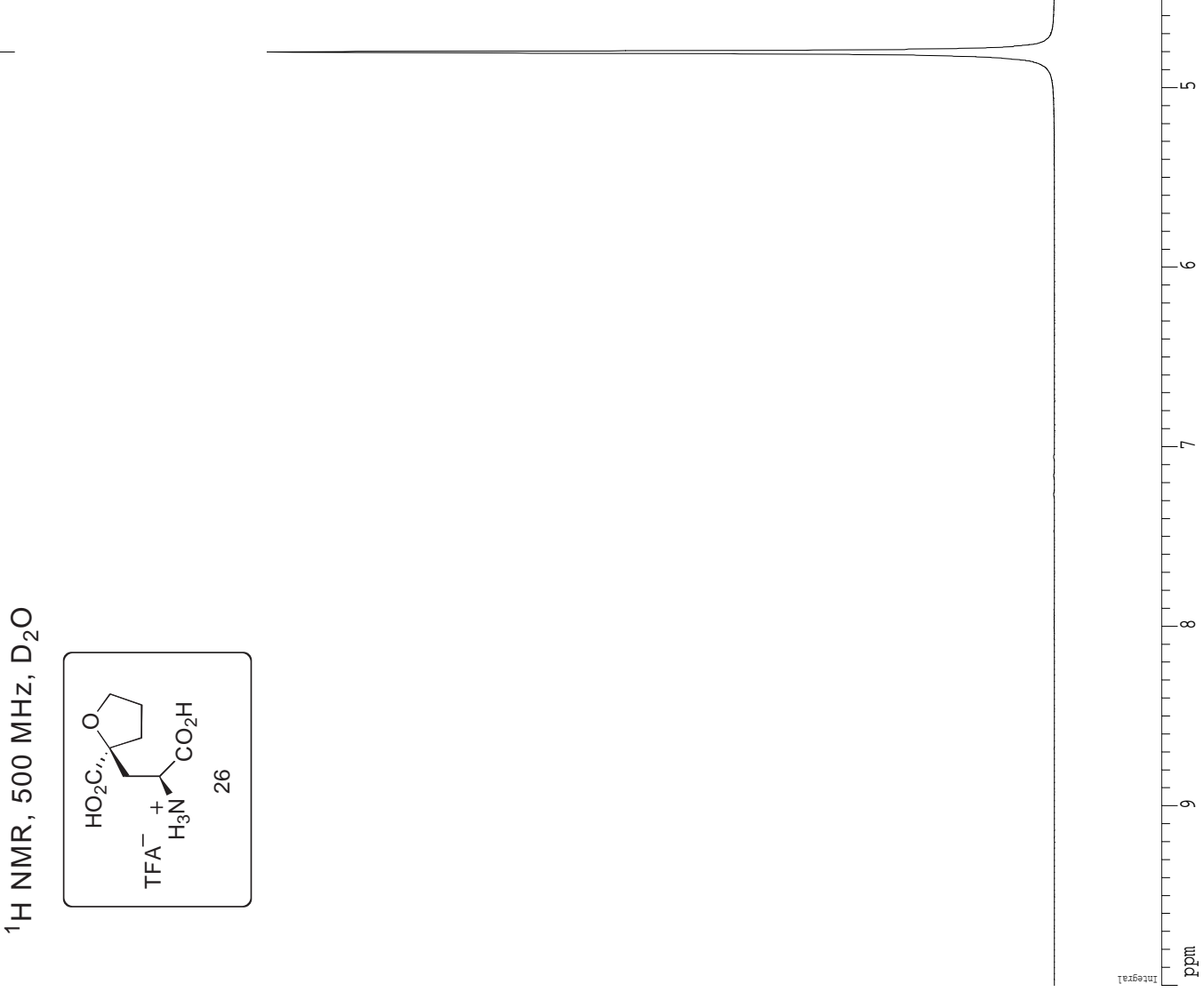

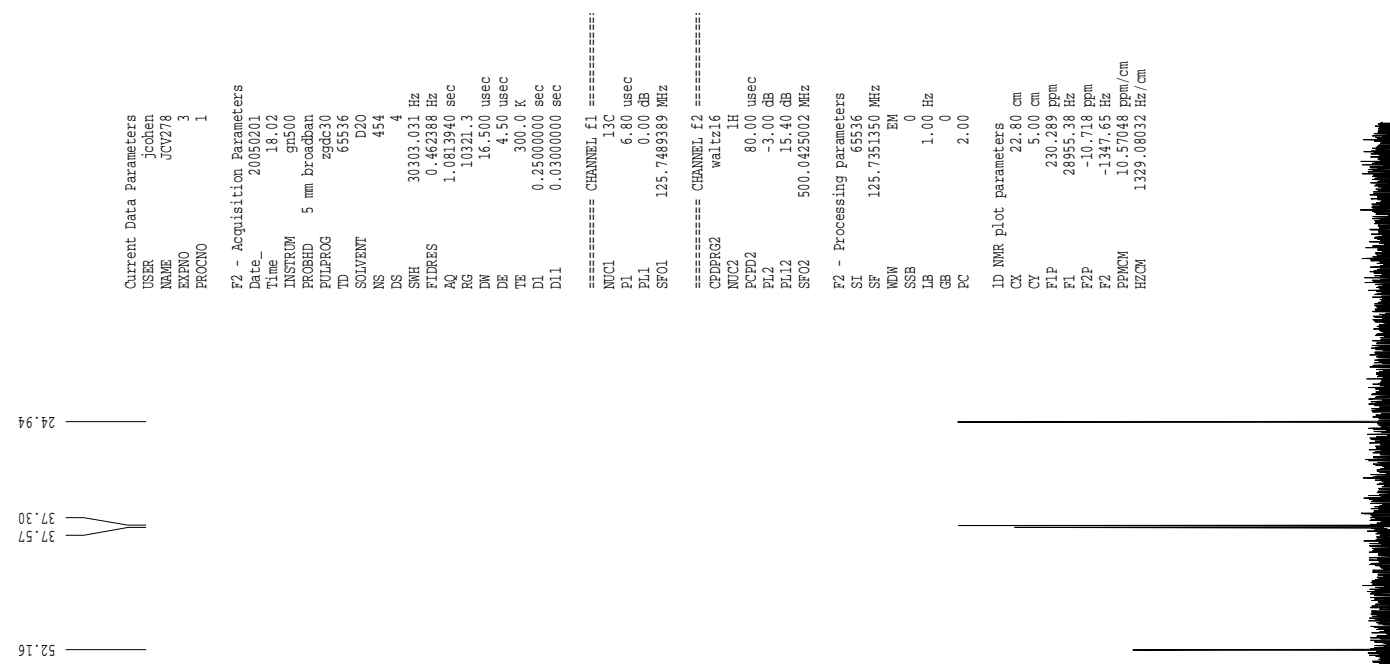

It $0 L$

69.58
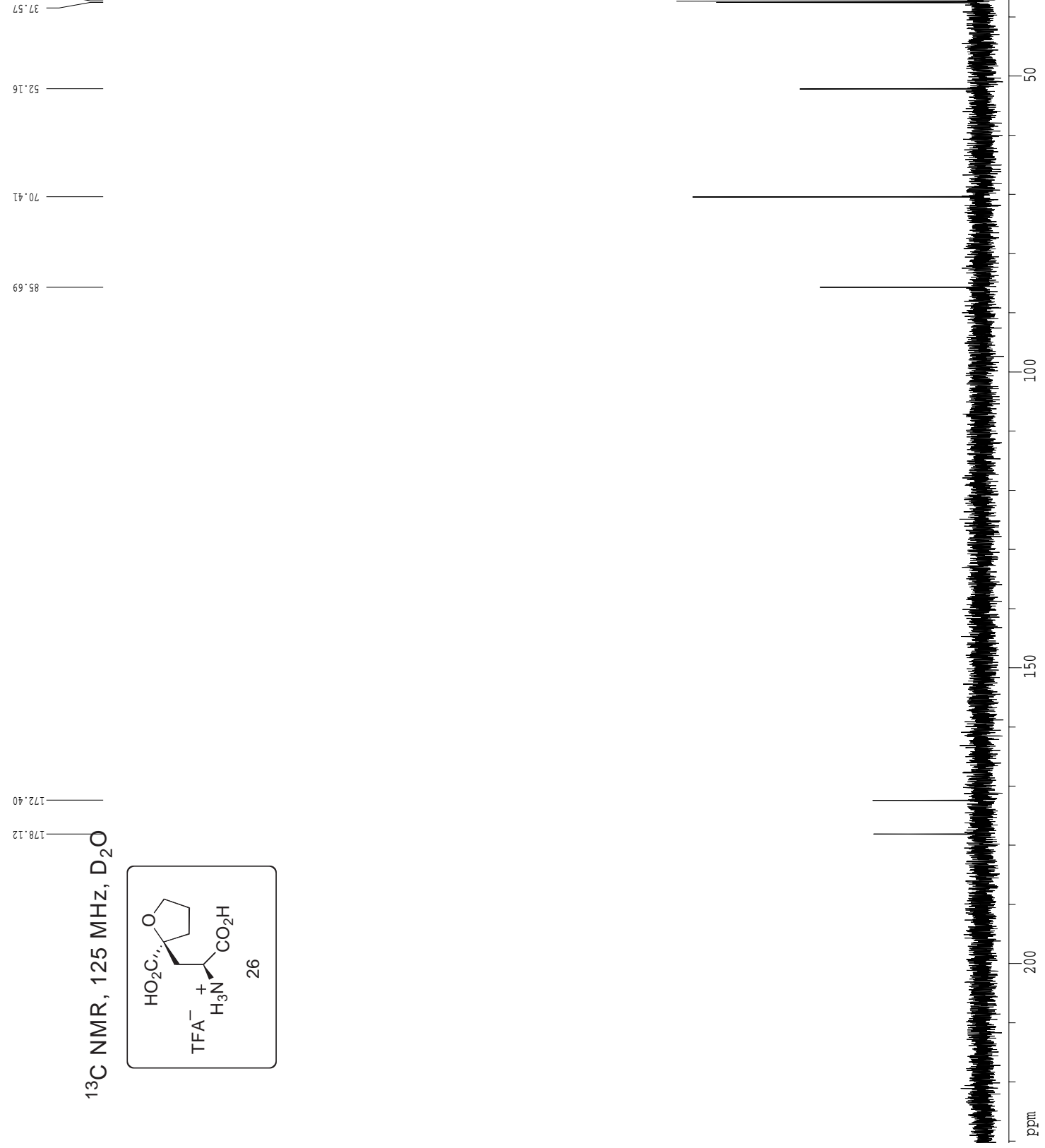

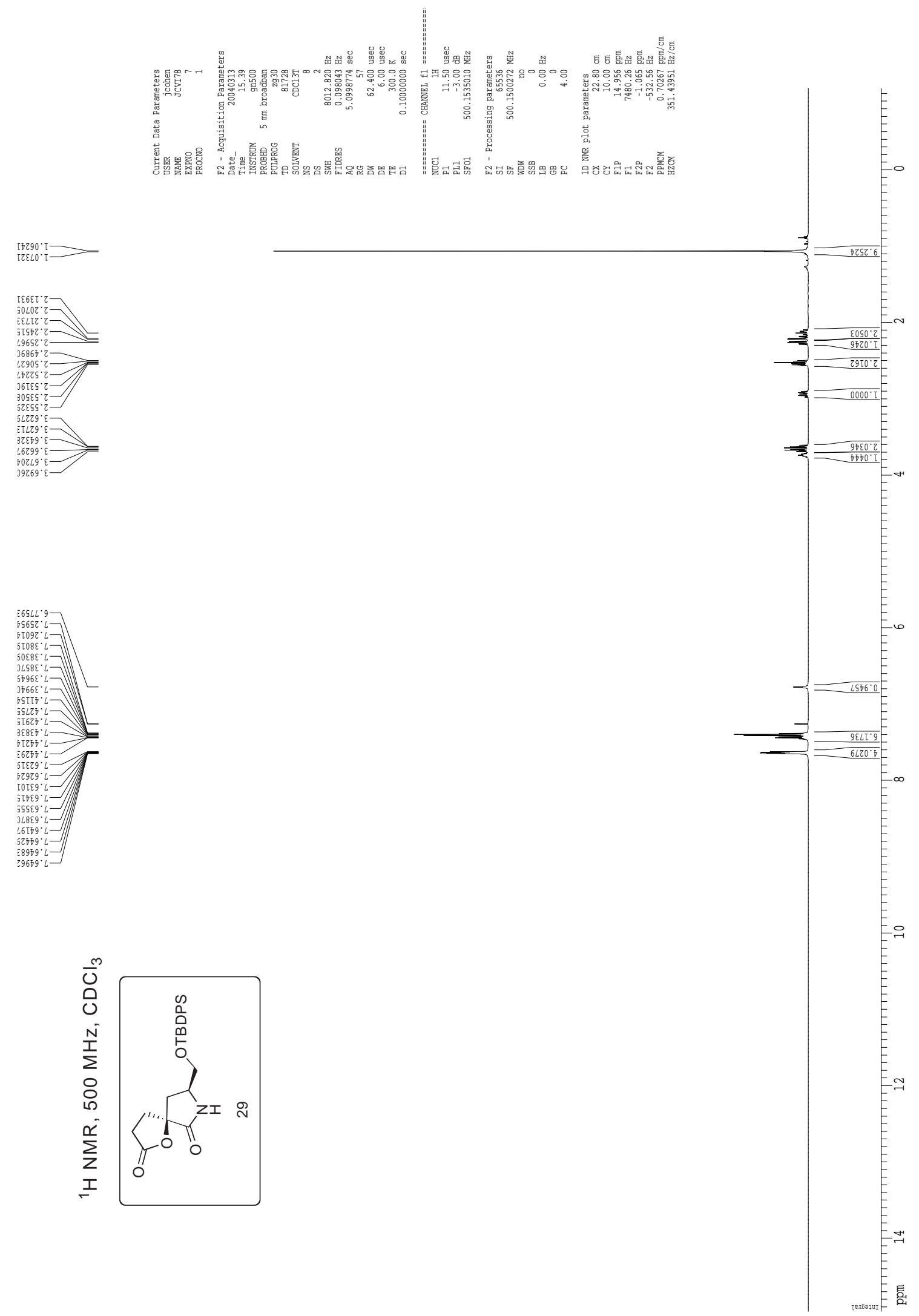

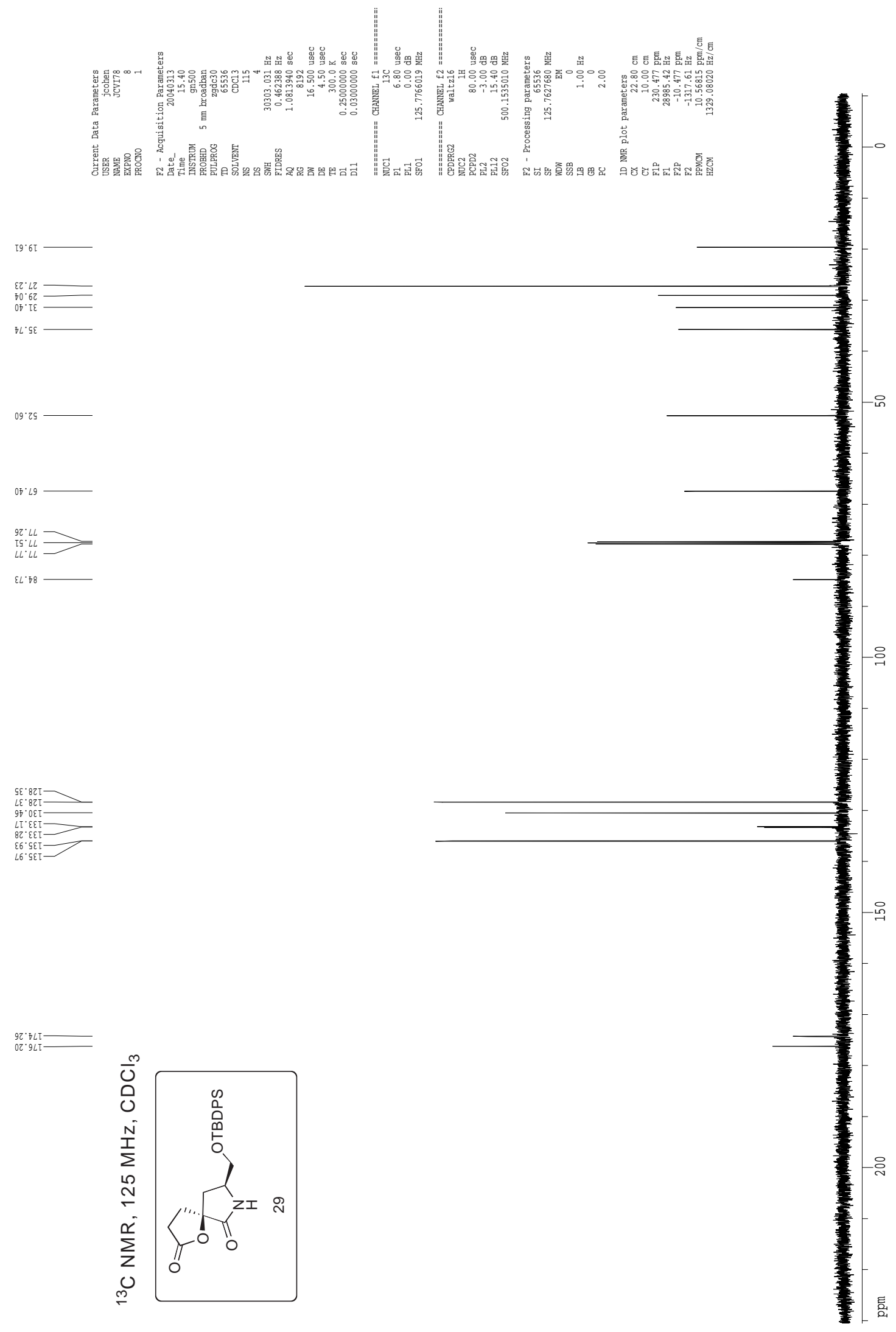


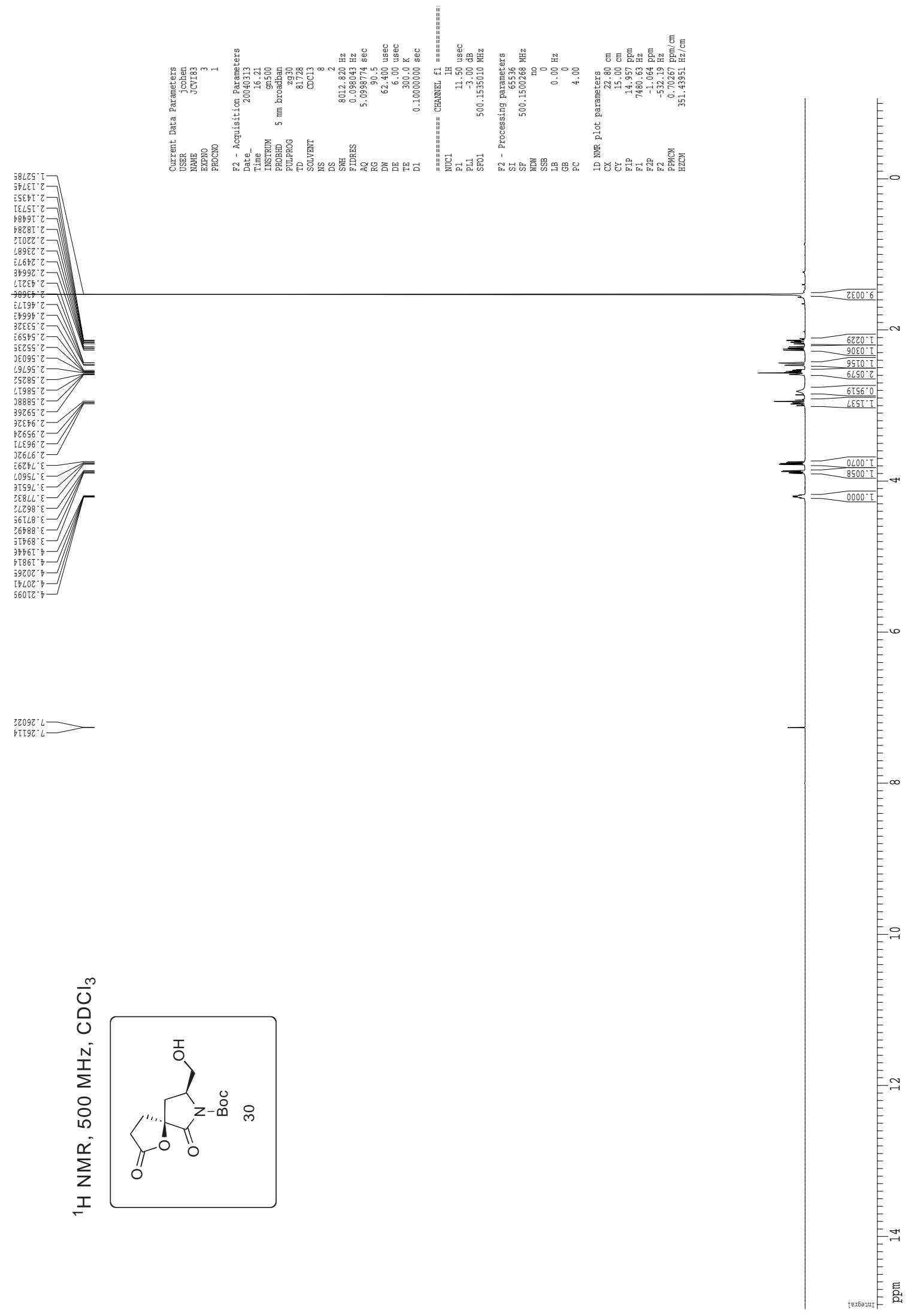




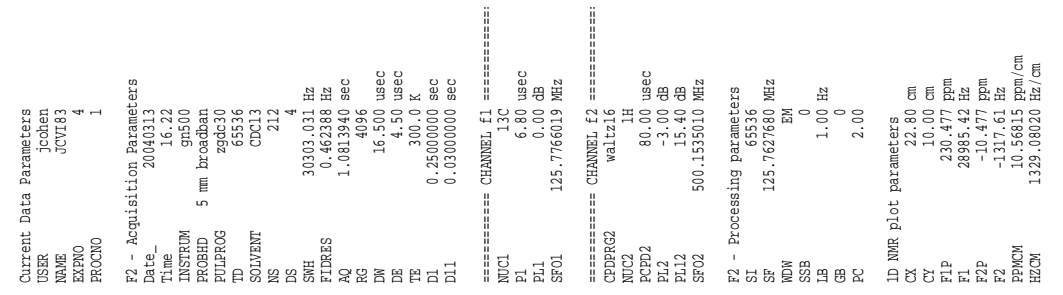

$5 \varepsilon \cdot 82$
$58 \cdot 82$
$08 \cdot 0 \varepsilon$
$09 \cdot \varepsilon \varepsilon$

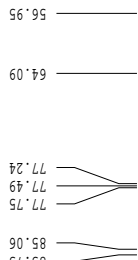

$90^{\circ} 58$

89. OST

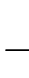




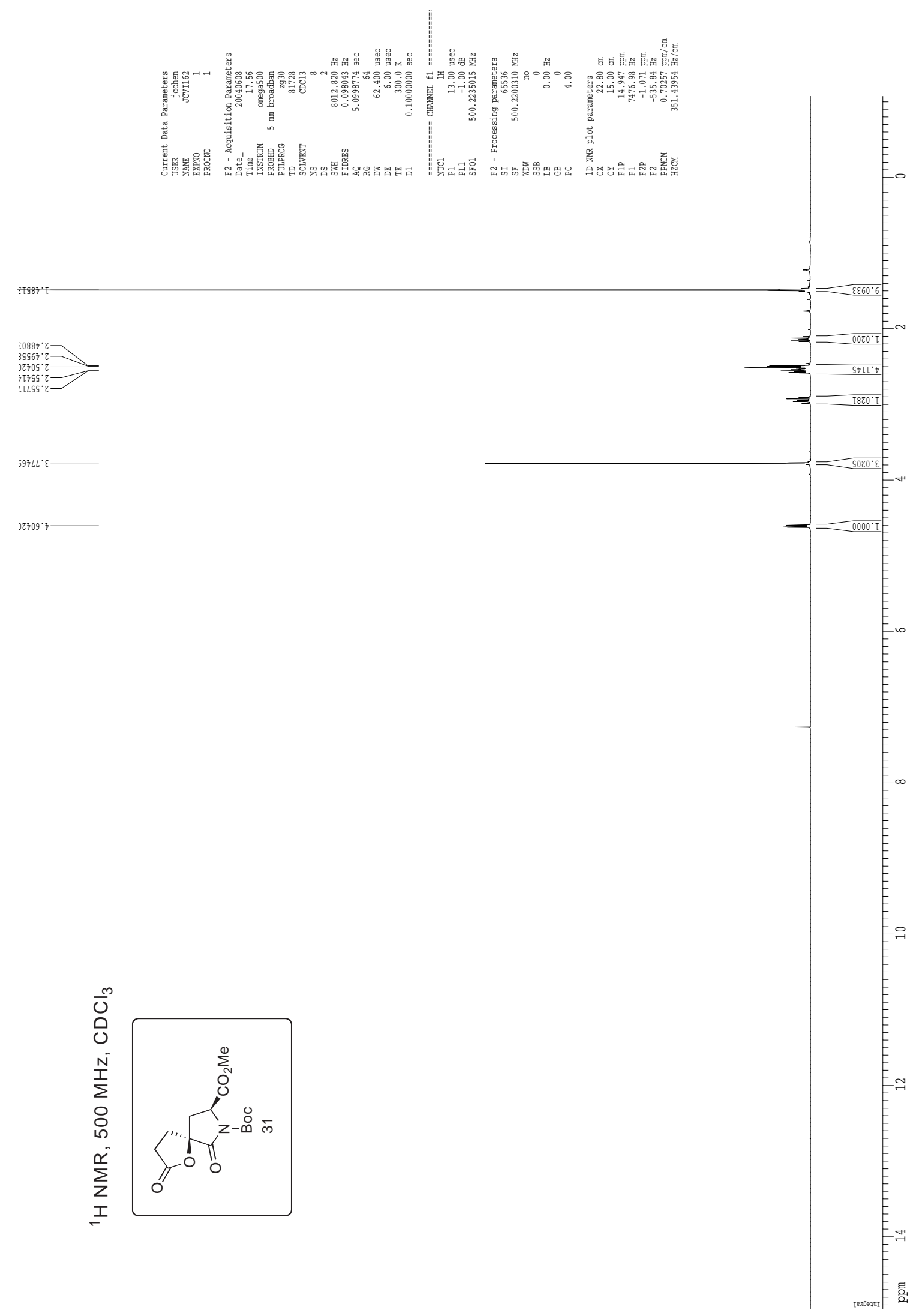




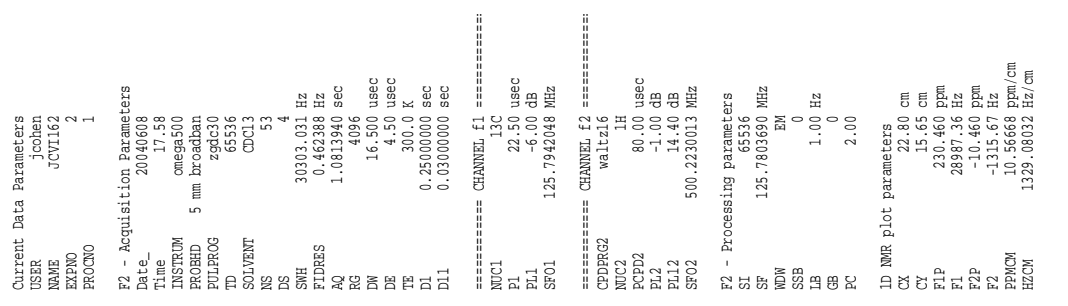

$52 \cdot 82=$
$89.82=$
$99^{\circ} 0 \varepsilon=$

$89^{\circ} 6 \varepsilon$

$8 \varepsilon^{\circ} \varepsilon \varsigma$
50.99

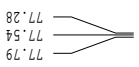

${ }_{02}^{60} \cdot 98=$

$0 \varepsilon^{\prime} 6 \mathrm{t} \mathrm{L}$
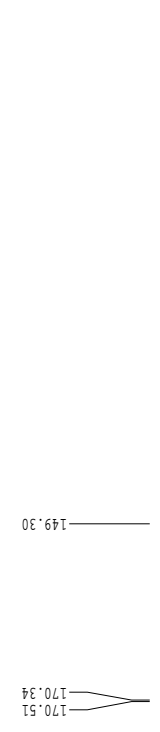

$9 \varepsilon \cdot$ GLT-
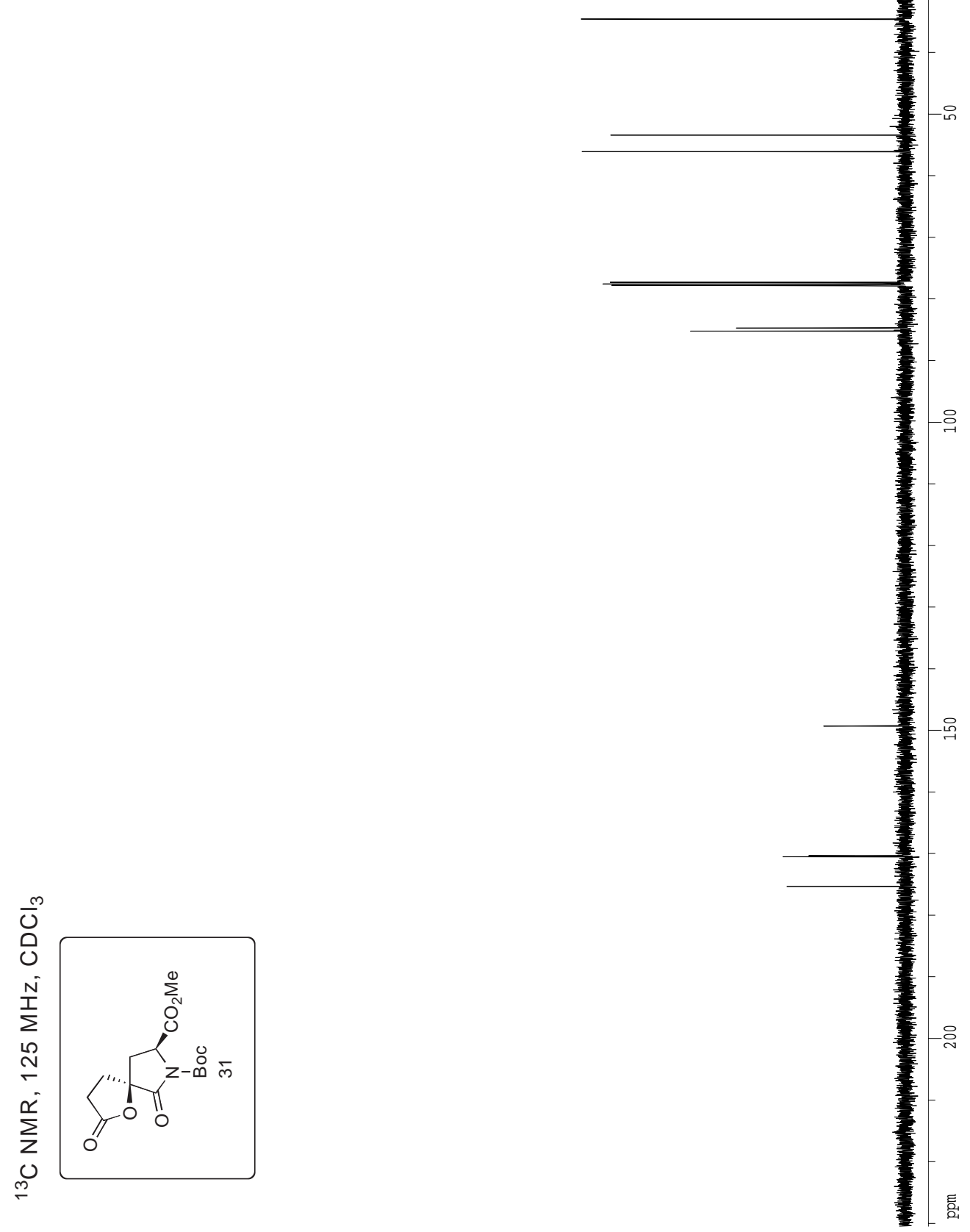


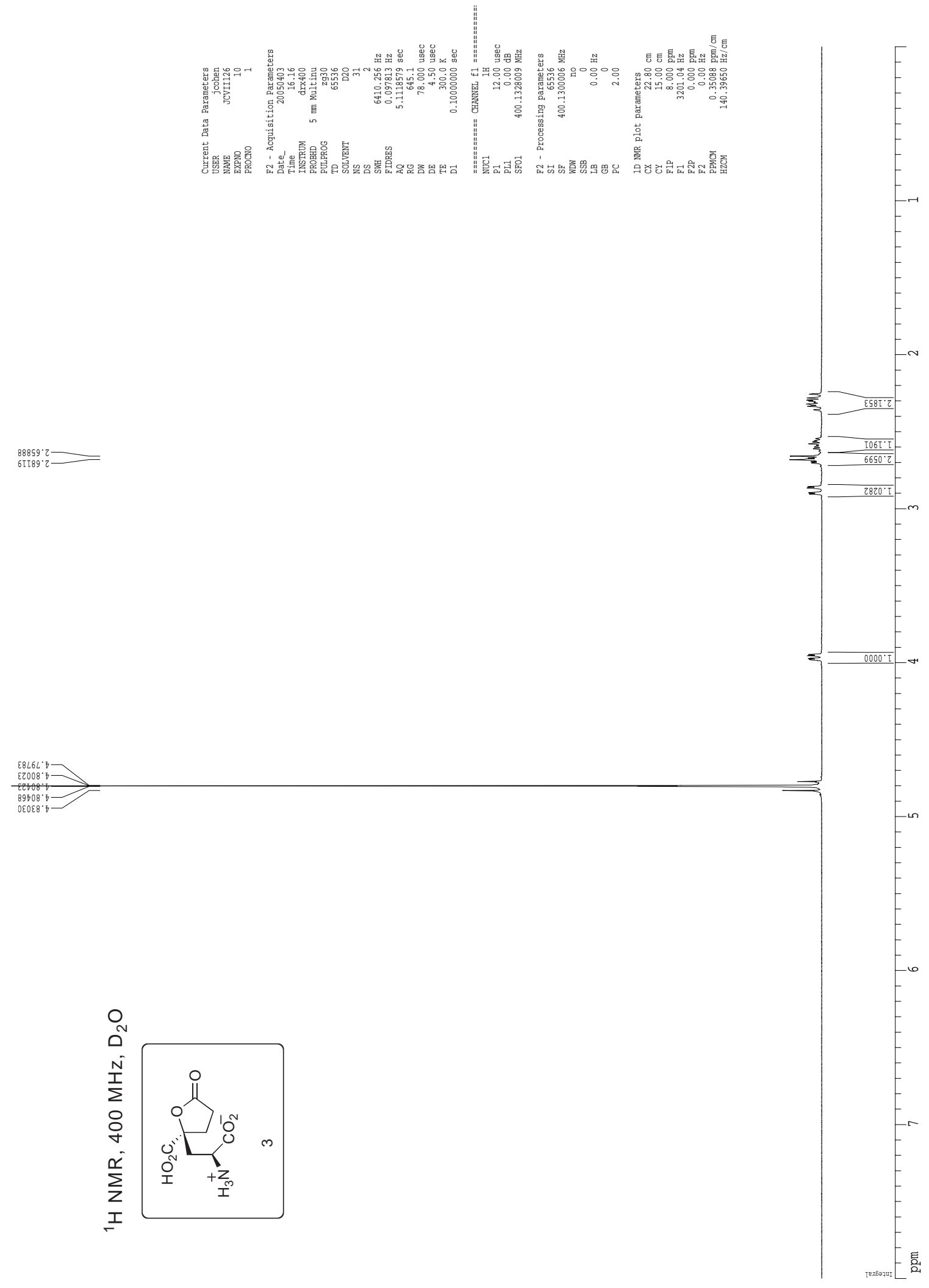



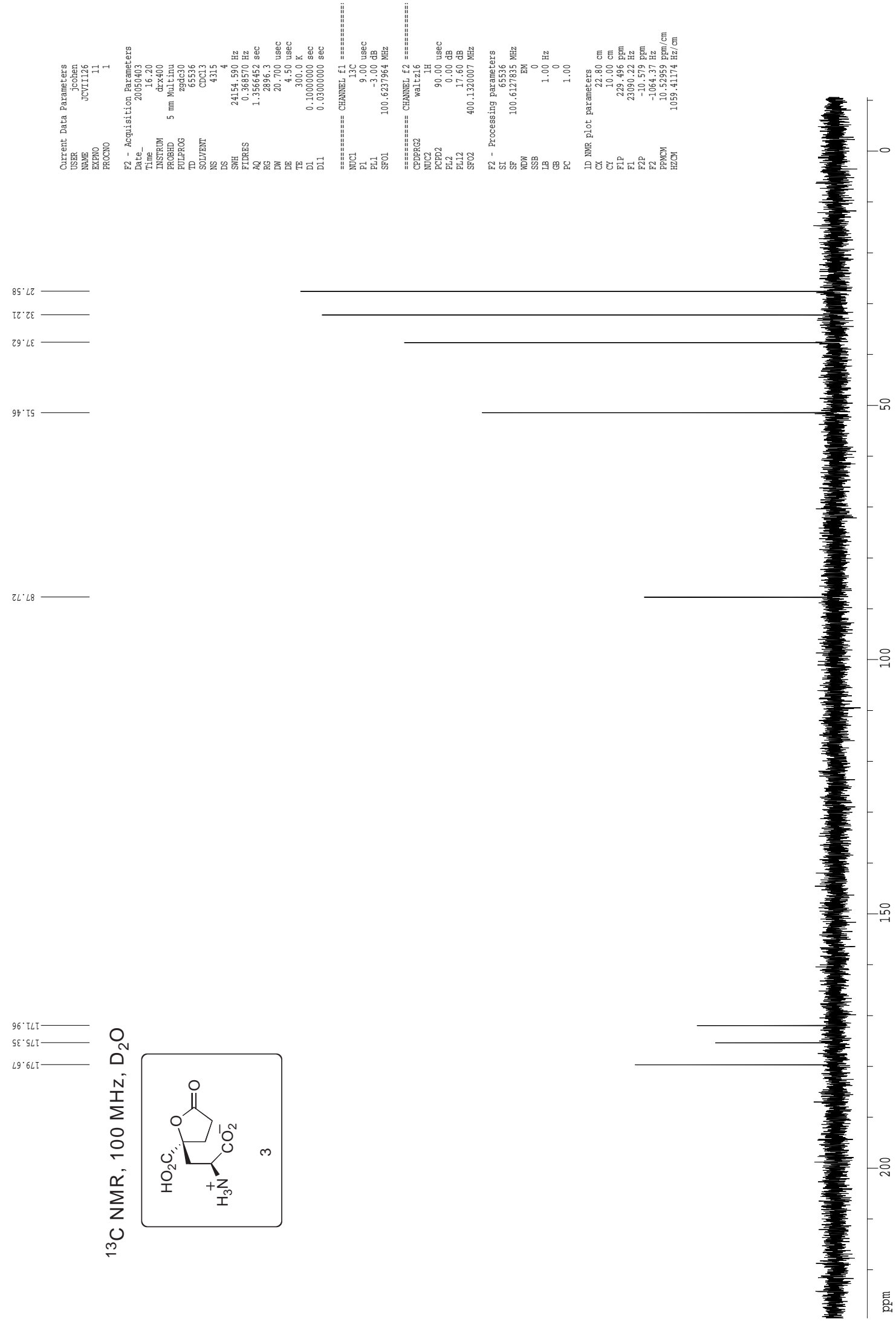


\section{X-Ray Crystallography Report for Lycoperdic Acid 3}

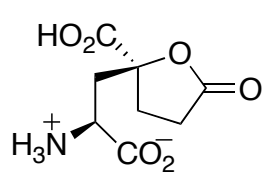

3

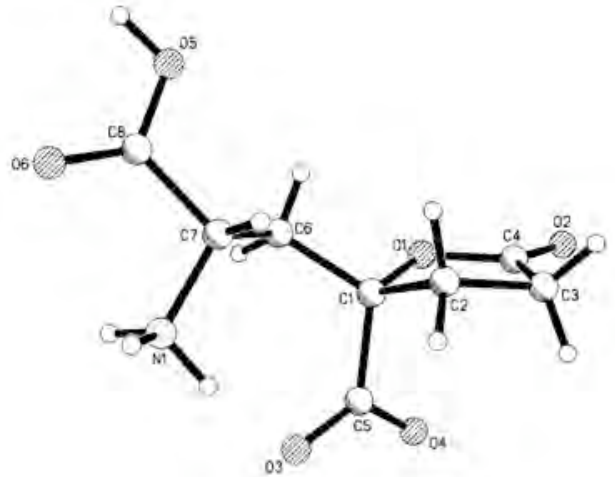

\section{X-ray Data Collection and Structure Refinement for 3 (CCDC 299403)}

A colorless crystal of approximate dimensions $0.09 \times 0.15 \times 0.26 \mathrm{~mm}$ was mounted on a glass fiber and transferred to a Bruker CCD platform diffractometer. The SMART ${ }^{1}$ program package was used to determine the unit-cell parameters and for data collection (40 sec/frame scan time for a hemisphere of diffraction data). The raw frame data was processed using $\mathrm{SAINT}^{2}$ and $\mathrm{SADABS}^{3}$ to yield the reflection data file. Subsequent calculations were carried out using the SHELXTL $^{4}$ program. The diffraction symmetry was $\mathrm{mmm}$ and the systematic absences were consistent with the orthorhombic space group $P 2_{1} 2_{1} 2_{1}$ which was later determined to be correct.

The structure was solved by direct methods and refined on $\mathrm{F}^{2}$ by full-matrix least-squares techniques. The analytical scattering factors ${ }^{5}$ for neutral atoms were used throughout the analysis. Hydrogen atoms were located from a difference-Fourier map and refined (x,y,z and fixed $\mathrm{U}_{\text {iso }}$ ). At convergence, $\mathrm{wR} 2=0.1104$ and $\mathrm{Goof}=1.048$ for 170 variables refined against 1865 data $(0.80 \AA)$. As a comparison for refinement on $\mathrm{F}, \mathrm{R} 1=0.0421$ for those 1637 data with I $>2.0 \sigma(\mathrm{I})$. Due to the absence of an atom heavier than oxygen, it was not possible to assign the absolute structure by inversion of the model or by refinement of the Flack parameter ${ }^{6}$.

Table 1 Crystal data and Structure Refinement for Lycoperdic Acid 3 (CCDC 299403)

Identification code

Empirical formula

Formula weight

Temperature

Wavelength

Crystal system

Space group

Unit cell dimensions

\section{3}

$\mathrm{C}_{8} \mathrm{H}_{11} \mathrm{~N} \mathrm{O}_{6}$

217.18

163(2) K

$0.71073 \AA$

Orthorhombic

$P 2{ }_{1} 2_{1} 2_{1}$

$\mathrm{a}=6.2699(14) \AA \quad \alpha=90^{\circ}$. 
Volume

$\mathrm{Z}$

Density (calculated)

Absorption coefficient

$\mathrm{F}(000)$

Crystal color

Crystal size

Theta range for data collection

Index ranges

Reflections collected

Independent reflections

Completeness to theta $=26.37^{\circ}$

Absorption correction

Max. and min. transmission

Refinement method

Data / restraints / parameters

Goodness-of-fit on $\mathrm{F}^{2}$

Final $\mathrm{R}$ indices $[\mathrm{I}>2 \operatorname{sigma}(\mathrm{I})=1637$ data $]$

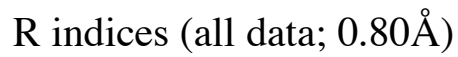

Largest diff. peak and hole $\mathrm{b}=6.4057(14) \AA \quad \beta=90^{\circ}$.

$\mathrm{c}=22.715(5) \AA \quad \gamma=90^{\circ}$.

912.3(4) $\AA^{3}$

4

$1.581 \mathrm{Mg} / \mathrm{m}^{3}$

$0.137 \mathrm{~mm}^{-1}$

456

colorless

$0.26 \times 0.15 \times 0.09 \mathrm{~mm}^{3}$

1.79 to $26.37^{\circ}$.

$-7 \leq h \leq 7,-8 \leq k \leq 6,-28 \leq l \leq 20$

5349

$1856[\mathrm{R}(\mathrm{int})=0.0432]$

$100.0 \%$

Semi-empirical from equivalents

0.9877 and 0.9651

Full-matrix least-squares on $\mathrm{F}^{2}$

1856 / 0 / 170

1.048

$\mathrm{R} 1=0.0421, \mathrm{wR} 2=0.1022$

$\mathrm{R} 1=0.0500, \mathrm{wR} 2=0.1104$

0.272 and -0.333 e. $\AA^{-3}$

Table 2 Atomic coordinates $\left(\mathrm{x} 10^{4}\right)$ and equivalent isotropic displacement parameters $\left(\AA^{2} \mathrm{x} 10^{3}\right)$ for 3 (CCDC 299403). U(eq) is defined as one third of the trace of the orthogonalized $U^{i j}$ tensor.

\begin{tabular}{lrrrr}
\hline & $\mathrm{x}$ & $\mathrm{y}$ & $\mathrm{z}$ & $\mathrm{U}(\mathrm{eq})$ \\
$\mathrm{N}(1)$ & $7900(3)$ & $9840(3)$ & $388(1)$ & $16(1)$ \\
$\mathrm{O}(1)$ & $9250(2)$ & $4422(2)$ & $1637(1)$ & $17(1)$ \\
$\mathrm{O}(2)$ & $8649(3)$ & $2304(3)$ & $2399(1)$ & $28(1)$ \\
$\mathrm{O}(3)$ & $5713(3)$ & $6308(2)$ & $529(1)$ & $21(1)$ \\
$\mathrm{O}(4)$ & $5986(3)$ & $3304(2)$ & $1020(1)$ & $19(1)$ \\
$\mathrm{O}(5)$ & $12788(3)$ & $10887(3)$ & $1148(1)$ & $24(1)$ \\
$\mathrm{O}(6)$ & $10999(3)$ & $12577(3)$ & $441(1)$ & $22(1)$ \\
$\mathrm{C}(1)$ & $8155(4)$ & $6140(3)$ & $1345(1)$ & $15(1)$
\end{tabular}




\begin{tabular}{lrrrr}
$\mathrm{C}(2)$ & $6920(4)$ & $7241(4)$ & $1847(1)$ & $17(1)$ \\
$\mathrm{C}(3)$ & $6491(4)$ & $5455(4)$ & $2277(1)$ & $23(1)$ \\
$\mathrm{C}(4)$ & $8192(4)$ & $3872(4)$ & $2132(1)$ & $20(1)$ \\
$\mathrm{C}(5)$ & $6496(3)$ & $5165(4)$ & $918(1)$ & $16(1)$ \\
$\mathrm{C}(6)$ & $9924(4)$ & $7470(4)$ & $1063(1)$ & $15(1)$ \\
$\mathrm{C}(7)$ & $9288(4)$ & $9716(3)$ & $917(1)$ & $15(1)$ \\
$\mathrm{C}(8)$ & $11147(4)$ & $11210(3)$ & $802(1)$ & $16(1)$ \\
\hline
\end{tabular}

Table 3 Bond lengths $[\AA ̊]$ and angles $\left[{ }^{\circ}\right]$ for 3 (CCDC 299403)

\begin{tabular}{|c|c|}
\hline$N(1)-C(7)$ & $1.486(3)$ \\
\hline $\mathrm{O}(1)-\mathrm{C}(4)$ & $1.352(3)$ \\
\hline $\mathrm{O}(1)-\mathrm{C}(1)$ & $1.457(2)$ \\
\hline $\mathrm{O}(2)-\mathrm{C}(4)$ & $1.207(3)$ \\
\hline $\mathrm{O}(3)-\mathrm{C}(5)$ & $1.249(3)$ \\
\hline $\mathrm{O}(4)-\mathrm{C}(5)$ & $1.256(3)$ \\
\hline $\mathrm{O}(5)-\mathrm{C}(8)$ & $1.312(3)$ \\
\hline $\mathrm{O}(6)-\mathrm{C}(8)$ & $1.202(3)$ \\
\hline$C(1)-C(6)$ & $1.537(3)$ \\
\hline$C(1)-C(2)$ & $1.550(3)$ \\
\hline$C(1)-C(5)$ & $1.553(3)$ \\
\hline$C(2)-C(3)$ & $1.528(3)$ \\
\hline$C(3)-C(4)$ & $1.508(3)$ \\
\hline$C(6)-C(7)$ & $1.530(3)$ \\
\hline$C(7)-C(8)$ & $1.531(3)$ \\
\hline $\mathrm{C}(4)-\mathrm{O}(1)-\mathrm{C}(1)$ & $110.17(17)$ \\
\hline $\mathrm{O}(1)-\mathrm{C}(1)-\mathrm{C}(6)$ & $105.55(17)$ \\
\hline $\mathrm{O}(1)-\mathrm{C}(1)-\mathrm{C}(2)$ & $104.10(17)$ \\
\hline$C(6)-C(1)-C(2)$ & $114.51(18)$ \\
\hline $\mathrm{O}(1)-\mathrm{C}(1)-\mathrm{C}(5)$ & 107.21(17) \\
\hline $\mathrm{C}(6)-\mathrm{C}(1)-\mathrm{C}(5)$ & $116.54(18)$ \\
\hline $\mathrm{C}(2)-\mathrm{C}(1)-\mathrm{C}(5)$ & 107.92(18) \\
\hline $\mathrm{C}(3)-\mathrm{C}(2)-\mathrm{C}(1)$ & $102.56(19)$ \\
\hline $\mathrm{C}(4)-\mathrm{C}(3)-\mathrm{C}(2)$ & 103.89(19) \\
\hline $\mathrm{O}(2)-\mathrm{C}(4)-\mathrm{O}(1)$ & $121.2(2)$ \\
\hline
\end{tabular}




$\begin{array}{ll}\mathrm{O}(2)-\mathrm{C}(4)-\mathrm{C}(3) & 128.2(2) \\ \mathrm{O}(1)-\mathrm{C}(4)-\mathrm{C}(3) & 110.67(19) \\ \mathrm{O}(3)-\mathrm{C}(5)-\mathrm{O}(4) & 126.0(2) \\ \mathrm{O}(3)-\mathrm{C}(5)-\mathrm{C}(1) & 117.97(19) \\ \mathrm{O}(4)-\mathrm{C}(5)-\mathrm{C}(1) & 115.9(2) \\ \mathrm{C}(7)-\mathrm{C}(6)-\mathrm{C}(1) & 115.04(18) \\ \mathrm{N}(1)-\mathrm{C}(7)-\mathrm{C}(6) & 112.25(18) \\ \mathrm{N}(1)-\mathrm{C}(7)-\mathrm{C}(8) & 105.94(17) \\ \mathrm{C}(6)-\mathrm{C}(7)-\mathrm{C}(8) & 115.24(19) \\ \mathrm{O}(6)-\mathrm{C}(8)-\mathrm{O}(5) & 125.7(2) \\ \mathrm{O}(6)-\mathrm{C}(8)-\mathrm{C}(7) & 120.8(2) \\ \mathrm{O}(5)-\mathrm{C}(8)-\mathrm{C}(7) & 113.36(18)\end{array}$

Table 4 Anisotropic displacement parameters $\left(\AA^{2} \mathrm{x} 10^{3}\right)$ for 3 (CCDC 299403). The anisotropic displacement factor exponent takes the form: $-2 \pi^{2}\left[h^{2} a^{* 2} U^{11}+\ldots+2 h k a^{*} b^{*} U^{12}\right]$

\begin{tabular}{lcccccc}
\hline & $\mathrm{U}^{11}$ & $\mathrm{U}^{22}$ & $\mathrm{U}^{33}$ & $\mathrm{U}^{23}$ & $\mathrm{U}^{13}$ & $\mathrm{U}^{12}$ \\
\hline $\mathrm{N}(1)$ & $16(1)$ & $15(1)$ & $17(1)$ & $4(1)$ & $1(1)$ & $0(1)$ \\
$\mathrm{O}(1)$ & $18(1)$ & $12(1)$ & $20(1)$ & $3(1)$ & $-3(1)$ & $0(1)$ \\
$\mathrm{O}(2)$ & $33(1)$ & $23(1)$ & $29(1)$ & $12(1)$ & $-4(1)$ & $-2(1)$ \\
$\mathrm{O}(3)$ & $23(1)$ & $18(1)$ & $21(1)$ & $3(1)$ & $-7(1)$ & $-5(1)$ \\
$\mathrm{O}(4)$ & $17(1)$ & $14(1)$ & $25(1)$ & $1(1)$ & $-1(1)$ & $-3(1)$ \\
$\mathrm{O}(5)$ & $19(1)$ & $20(1)$ & $33(1)$ & $7(1)$ & $-5(1)$ & $-7(1)$ \\
$\mathrm{O}(6)$ & $27(1)$ & $19(1)$ & $21(1)$ & $6(1)$ & $1(1)$ & $-6(1)$ \\
$\mathrm{C}(1)$ & $16(1)$ & $13(1)$ & $15(1)$ & $1(1)$ & $-2(1)$ & $2(1)$ \\
$\mathrm{C}(2)$ & $18(1)$ & $17(1)$ & $15(1)$ & $-1(1)$ & $2(1)$ & $0(1)$ \\
$\mathrm{C}(3)$ & $27(1)$ & $21(1)$ & $20(1)$ & $0(1)$ & $5(1)$ & $-3(1)$ \\
$\mathrm{C}(4)$ & $24(1)$ & $19(1)$ & $18(1)$ & $2(1)$ & $-5(1)$ & $-5(1)$ \\
$\mathrm{C}(5)$ & $15(1)$ & $15(1)$ & $16(1)$ & $-2(1)$ & $3(1)$ & $-1(1)$ \\
$\mathrm{C}(6)$ & $14(1)$ & $13(1)$ & $17(1)$ & $1(1)$ & $-2(1)$ & $1(1)$ \\
$\mathrm{C}(7)$ & $18(1)$ & $14(1)$ & $15(1)$ & $2(1)$ & $0(1)$ & $-1(1)$ \\
$\mathrm{C}(8)$ & $18(1)$ & $15(1)$ & $15(1)$ & $-2(1)$ & $2(1)$ & $-2(1)$ \\
\hline
\end{tabular}


Table 5 Hydrogen coordinates (x 104) and isotropic displacement parameters $\left(\AA^{2} \mathrm{x} 10^{3}\right)$ for 3 (CCDC 299403).

\begin{tabular}{lrrrr}
\hline & \multicolumn{1}{c}{$\mathrm{x}$} & $\mathrm{z}$ & $\mathrm{U}(\mathrm{eq})$ \\
\hline $\mathrm{H}(1 \mathrm{~A})$ & $8690(50)$ & $9630(40)$ & $52(13)$ & $29(2)$ \\
$\mathrm{H}(1 \mathrm{~B})$ & $6870(50)$ & $8720(40)$ & $414(13)$ & $29(2)$ \\
$\mathrm{H}(1 \mathrm{C})$ & $7200(50)$ & $11220(40)$ & $366(12)$ & $29(2)$ \\
$\mathrm{H}(2 \mathrm{~A})$ & $5530(50)$ & $7830(50)$ & $1697(13)$ & $29(2)$ \\
$\mathrm{H}(2 \mathrm{~B})$ & $7950(50)$ & $8280(40)$ & $2030(13)$ & $29(2)$ \\
$\mathrm{H}(3 \mathrm{~A})$ & $5090(50)$ & $4840(50)$ & $2205(12)$ & $29(2)$ \\
$\mathrm{H}(3 \mathrm{~B})$ & $6550(50)$ & $5860(40)$ & $2678(13)$ & $29(2)$ \\
$\mathrm{H}(5)$ & $13740(50)$ & $11810(50)$ & $1074(13)$ & $29(2)$ \\
$\mathrm{H}(6 \mathrm{~A})$ & $10950(50)$ & $7470(50)$ & $1352(12)$ & $29(2)$ \\
$\mathrm{H}(6 \mathrm{~B})$ & $10450(50)$ & $6770(40)$ & $713(12)$ & $29(2)$ \\
$\mathrm{H}(7)$ & $8570(40)$ & $10400(50)$ & $1240(13)$ & $29(2)$ \\
& & & & \\
\hline
\end{tabular}

Table 6 Torsion angles $\left[{ }^{\circ}\right]$ for 3 (CCDC 299403)

$\begin{array}{lc}\mathrm{C}(4)-\mathrm{O}(1)-\mathrm{C}(1)-\mathrm{C}(6) & 146.19(18) \\ \mathrm{C}(4)-\mathrm{O}(1)-\mathrm{C}(1)-\mathrm{C}(2) & 25.3(2) \\ \mathrm{C}(4)-\mathrm{O}(1)-\mathrm{C}(1)-\mathrm{C}(5) & -88.9(2) \\ \mathrm{O}(1)-\mathrm{C}(1)-\mathrm{C}(2)-\mathrm{C}(3) & -29.1(2) \\ \mathrm{C}(6)-\mathrm{C}(1)-\mathrm{C}(2)-\mathrm{C}(3) & -143.9(2) \\ \mathrm{C}(5)-\mathrm{C}(1)-\mathrm{C}(2)-\mathrm{C}(3) & 84.6(2) \\ \mathrm{C}(1)-\mathrm{C}(2)-\mathrm{C}(3)-\mathrm{C}(4) & 23.0(2) \\ \mathrm{C}(1)-\mathrm{O}(1)-\mathrm{C}(4)-\mathrm{O}(2) & 169.7(2) \\ \mathrm{C}(1)-\mathrm{O}(1)-\mathrm{C}(4)-\mathrm{C}(3) & -10.5(2) \\ \mathrm{C}(2)-\mathrm{C}(3)-\mathrm{C}(4)-\mathrm{O}(2) & 170.8(2) \\ \mathrm{C}(2)-\mathrm{C}(3)-\mathrm{C}(4)-\mathrm{O}(1) & -8.9(3) \\ \mathrm{O}(1)-\mathrm{C}(1)-\mathrm{C}(5)-\mathrm{O}(3) & -164.28(18) \\ \mathrm{C}(6)-\mathrm{C}(1)-\mathrm{C}(5)-\mathrm{O}(3) & -46.3(3) \\ \mathrm{C}(2)-\mathrm{C}(1)-\mathrm{C}(5)-\mathrm{O}(3) & 84.1(2) \\ \mathrm{O}(1)-\mathrm{C}(1)-\mathrm{C}(5)-\mathrm{O}(4) & 19.3(2) \\ \mathrm{C}(6)-\mathrm{C}(1)-\mathrm{C}(5)-\mathrm{O}(4) & 137.27(19)\end{array}$


$\mathrm{C}(2)-\mathrm{C}(1)-\mathrm{C}(5)-\mathrm{O}(4)$

$\mathrm{O}(1)-\mathrm{C}(1)-\mathrm{C}(6)-\mathrm{C}(7)$

$\mathrm{C}(2)-\mathrm{C}(1)-\mathrm{C}(6)-\mathrm{C}(7)$

$\mathrm{C}(5)-\mathrm{C}(1)-\mathrm{C}(6)-\mathrm{C}(7)$

$\mathrm{C}(1)-\mathrm{C}(6)-\mathrm{C}(7)-\mathrm{N}(1)$

$\mathrm{C}(1)-\mathrm{C}(6)-\mathrm{C}(7)-\mathrm{C}(8)$

$\mathrm{N}(1)-\mathrm{C}(7)-\mathrm{C}(8)-\mathrm{O}(6)$

$\mathrm{C}(6)-\mathrm{C}(7)-\mathrm{C}(8)-\mathrm{O}(6)$

$\mathrm{N}(1)-\mathrm{C}(7)-\mathrm{C}(8)-\mathrm{O}(5)$

$\mathrm{C}(6)-\mathrm{C}(7)-\mathrm{C}(8)-\mathrm{O}(5)$
$-92.3(2)$

$-159.75(17)$

$-45.9(3)$

81.4(2)

$-75.0(2)$

163.61(19)

20.0(3)

$144.8(2)$

$-162.96(18)$

$-38.2(3)$

\section{References}

1. SMART Software Users Guide, Version 5.1, Bruker Analytical X-Ray Systems, Inc.; Madison, WI 1999.

2. SAINT Software Users Guide, Version 6.0, Bruker Analytical X-Ray Systems, Inc.; Madison, WI 1999.

3. Sheldrick, G. M. SADABS, Version 2.10, Bruker Analytical X-Ray Systems, Inc.; Madison, WI 2002.

4. Sheldrick, G. M. SHELXTL Version 6.12, Bruker Analytical X-Ray Systems, Inc.; Madison, WI 2001.

5. International Tables for X-Ray Crystallography 1992, Vol. C., Dordrecht: Kluwer Academic Publishers.

6. Flack, H. D. Acta. Cryst., A39, 876-881, 1983.

\section{Definitions:}

$\mathrm{wR} 2=\left[\Sigma\left[\mathrm{w}\left(\mathrm{F}_{\mathrm{o}}^{2}-\mathrm{F}_{\mathrm{c}}^{2}\right)^{2}\right] / \Sigma\left[\mathrm{w}\left(\mathrm{F}_{\mathrm{o}}^{2}\right)^{2}\right]\right]^{1 / 2}$

$\mathrm{R} 1=\Sigma\left\|\mathrm{F}_{\mathrm{o}} \mathrm{l}-\mathrm{F}_{\mathrm{c}}\right\| / \Sigma \mid \mathrm{F}_{\mathrm{o}} \mathrm{I}$

Goof $=\mathrm{S}=\left[\Sigma\left[\mathrm{w}\left(\mathrm{F}_{\mathrm{o}}{ }^{2}-\mathrm{F}_{\mathrm{c}}{ }^{2}\right)^{2}\right] /(\mathrm{n}-\mathrm{p})\right]^{1 / 2}$ where $\mathrm{n}$ is the number of reflections and $\mathrm{p}$ is the total number of parameters refined.

The thermal ellipsoid plot is shown at the $50 \%$ probability level. 